\title{
Hitting the Target but Missing the Point: Recent Progress towards Adenovirus-Based Precision Virotherapies
}

\author{
Tabitha G. Cunliffe ${ }^{\dagger}$, Emily A. Bates ${ }^{\dagger}$ and Alan L. Parker ${ }^{*}$ (D) \\ Division of Cancer and Genetics, School of Medicine, Cardiff University, Cardiff CF14 4XN, UK; \\ cunliffetg@cardiff.ac.uk (T.G.C.); batese@cardiff.ac.uk (E.A.B.) \\ * Correspondence: parkeral@cardiff.ac.uk \\ + Authors contributed equally to this work.
}

Received: 4 October 2020; Accepted: 9 November 2020; Published: 11 November 2020

Simple Summary: If harnessed appropriately, oncolytic viruses offer significant potential as anti-cancer agents. Such virotherapies can be engineered to replicate inside cancerous cells, stimulating the immune system, spreading daughter virions to surrounding cells and producing additional anticancer agents as a by-product of infection. To achieve this necessitates deep understanding of the biology of the virus and tumour cell, to tailor viruses from naturally pathogenic agents into refined, tumour selective "precision virotherapies" suitable for clinical translation. Here, we focus on the adenovirus, which in its pathogenic form causes transient and mild ocular, respiratory or gastrointestinal tract infections, depending on the serotype. We highlight advances that have been made in refining adenovirus to ablate natural means of infection and the strategies that have been employed to engineer viral tropism and selectivity for tumour cells. Further advances in these strategies will be required to deliver fully bespoke and efficacious precision virotherapies to the clinic.

\begin{abstract}
More people are surviving longer with cancer. Whilst this can be partially attributed to advances in early detection of cancers, there is little doubt that the improvement in survival statistics is also due to the expansion in the spectrum of treatments available for efficacious treatment. Transformative amongst those are immunotherapies, which have proven effective agents for treating immunogenic forms of cancer, although immunologically "cold" tumour types remain refractive. Oncolytic viruses, such as those based on adenovirus, have great potential as anti-cancer agents and have seen a resurgence of interest in recent years. Amongst their many advantages is their ability to induce immunogenic cell death (ICD) of infected tumour cells, thus providing the alluring potential to synergise with immunotherapies by turning immunologically "cold" tumours "hot". Additionally, enhanced immune mediated cell killing can be promoted through the local overexpression of immunological transgenes, encoded from within the engineered viral genome. To achieve this full potential requires the development of refined, tumour selective "precision virotherapies" that are extensively engineered to prevent off-target up take via native routes of infection and targeted to infect and replicate uniquely within malignantly transformed cells. Here, we review the latest advances towards this holy grail within the adenoviral field.
\end{abstract}

Keywords: adenovirus; oncolytic; virotherapy; targeting; immunotherapy; immunogenic cell death; $\alpha \mathrm{v} \beta 6$ integrin

\section{Introduction}

Cancer treatment has come a long way in recent years, with 10-year survival rates increasing to around $50 \%$, double that of 40 years ago [1]. While some of these improvements are credited 
to better and earlier diagnoses, a proportion of the advances in survival rates are attributable to the better understanding of cancer genetics, and thus how a patient may respond to a particular treatment. These advances have allowed clinicians to design and implement more efficacious and safer personalised treatment plans. Despite these advances, more progress remains to be made until fully personalised medicines are available for all patients. The need for such specific knowledge with a range of treatment options can lead onto the emerging era of targeted cancer medicines, in which the therapies act on a specific molecular target associated with the patient's cancer [2]. Some targeted therapeutics are already being used as the first line treatment for patients in the clinic, such as the monoclonal antibodies Herceptin and the newer pertuzumab that target the receptor HER2, which is overexpressed in cancers such as metastatic breast cancer [3-5]. Herceptin treatment in patients with HER2 overexpressing tumours results in significantly better survival rates [6]. Despite these advances in targeted therapies, continued progress into the understanding of cancer-specific markers, such as upregulated HER2, and the development of targeted treatments are required to improve patient survival further.

\subsection{Use of Targeted Therapies}

Targeted therapies can come in many forms, from antibody treatments, such as Herceptin, or treatment involving inhibitors to important enzymes, including upregulated kinases, such as mitogen-activated protein kinase 3 (MAPK3), which has abnormal expression in many forms of cancer [2]. Small molecular weight cancer drugs are also important since they readily enter cells and affect changes compared to large molecular weight drugs such as antibodies. These inhibitors can be used to target and block many enzymatic pathways which support cancer progression. For example, vascular endothelial growth factor receptor (VEGFR) inhibitors which aim to reduce angiogenesis are currently being developed, with just under 20 different molecules being tested in in vitro and clinical trials [7].

\subsection{Oncolytic Viruses}

One rejuvenated area of research for targeted therapy is oncolytic viruses (OVs). These cancer-killing viruses exploit the natural ability of a virus to infect, replicate and lyse cells. An additional benefit of OVs is that the lytic nature of cell killing induces immunogenic cell death (ICD), increasing recruitment of immune cells to the tumour site. This ability of OVs to enhance host anti-tumour immune responses through ICD has the potential to turn immunologically "cold" tumours "hot", thus sensitising otherwise refractory tumours to subsequent immunotherapies. This exciting potential of OVs to synergise with immunotherapies is the subject of significant ongoing clinical investigation, with compelling preliminary data obtained in several early phase clinical trials in brain tumours [8] and breast cancer [9], with other trials continuing in sarcoma, melanoma and breast cancer [10-12]. Efficacy may be further enhanced, with correspondingly reduced dose-limiting toxicities, through the development of rationally and effectively tumour targeted OVs suitable for intravenous applications.

The overarching aim in the development of OVs is to engineer viruses that can selectively target and/or replicate within cancer cells, leaving normal cells and tissues uninfected. The pro-immunogenic environment induced by OVs through the release of tumour antigens during cell lysis can be further enhanced by engineering the viral genome to over-express therapeutic transgenes, thus adding an extra layer to their therapeutic power. These multiple levels of activity are overviewed in Figure 1.

To limit "off target" uptake of OVs and subsequent killing of healthy cells, genetic engineering approaches have been undertaken. These have broadly focused on two approaches-firstly the active targeting of virions to tumour cells through the manipulation of viral capsid proteins to enhance uptake of virus into tumour cells and limit uptake via healthy cells. This has been largely achieved through the rational engineering of the viral genome and thus capsid to engineer tumour tropism via tumour associated antigens and receptors [13-15]. A second approach is to engineer in selectivity "post entry", 
such that viral replication is blocked in non-transformed cells, but subtle modifications within the viral early genes permit replication to proceed within malignantly transformed cells. Using combinations of these approaches, it is possible to achieve tightly controlled tumour cell killing, and thus creating a more effective cancer treatment.

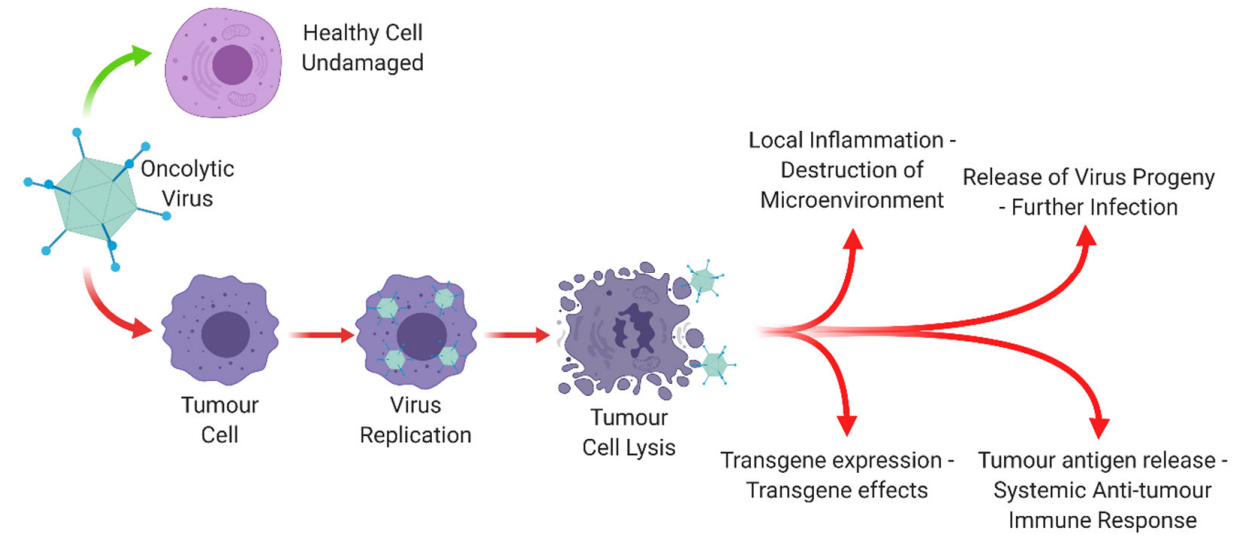

Figure 1. The mode of action of an oncolytic virus. Oncolytic viruses leave healthy cells undamaged, whilst leading to a range of effects in tumour cells which lead to lysis, further infection and an immunological response. Created with https://biorender.com.

The first OV licensed in the western world by both the FDA and EMA is talimogene laherparepvec (T-Vec, Imlygic $\left.{ }^{\mathrm{TM}}\right)$, which exemplifies the early therapeutic potential of oncolytic viruses. T-Vec is a herpes simplex virus 1, with several genetic modifications. Deletions of the ICP34.5 gene reduces neurovirulence whilst also suppressing its ability to reactivate, which prevents it producing cold sores in the patient. A deletion in the ICP47 gene leads to enhanced antigen loading on MHC class I molecules. The MHC loading results in infected cells presenting tumour antigens, leading to enhanced immune recognition. These deletions improve the safety of this treatment as it limits the ability of the virus to completely evade immune responses. In addition, T-Vec is engineered to overexpress the cytokine GM-CSF (granulocyte-macrophage colony-stimulating factor) to further enhance immunogenicity through T-cell priming [16]. A truncated version of the US11 gene is also included to enhance the lytic activity of the virus by partial de-attenuation [17]. The virus takes advantage of disrupted anti-viral pathways in cancer cells to enable selective virus replication. One such pathway is the PKR (protein kinase R) pathway which is key in regulating cell proliferation. Normally, this pathway is activated by the dsRNA produced when the virus replicates, thus triggering protein synthesis inhibition. However, in cancer cells with aberrant regulation, the dsRNA production warning sign is ignored, allowing the virus to replicate, leading to viral propagation and cell lysis. Disruption in the PKR pathway has been found in approximately $70 \%$ of melanoma cells, and thus T-Vec is a good replication selective therapy for melanoma cancers $[18,19]$.

$\mathrm{T}-\mathrm{Vec}$ was licensed for localised treatment of recurrent melanoma [20,21]. In phase III trials using $\mathrm{T}-\mathrm{Vec}$ to treat unresectable late stage melanoma, durable response rates of $16 \%$ vs. $2 \%$ were shown, compared to control group, increasing the survival rates of these patients [22,23]. Moreover, recent studies have demonstrated that virotherapies such as T-Vec can be a powerful tool in adjuvant therapy and have been used to sensitise triple negative breast cancers to follow up treatment with immunotherapies $[9,24]$.

\subsection{Adenovirus as an Oncolytic Virotherapy}

Despite the success of T-Vec, the therapy is only licensed for local intra-tumoural applications. Therefore, its use for treatment of metastases, which kills the majority of cancer patients, is limited. Metastasis treatment would require blood system disseminated therapy to individually target each lesion through intravenous (IV) delivery, or utilising the abscopal effect from treatment of one or more 
lesions, which could lead to a systemic anti-tumour immune response extending to the milieu of micro metastatic deposits in the body [25-27]. Therefore, significant research is ongoing into other viral vectors that may be better suited to IV delivery, including adenoviruses (Ads) [28], reovirus [29] and vaccinia virus [30]. Ads have been shown to be the most durable of these options and are the most studied clinically and experimentally. Ads also have the advantage of being naturally lytic, immunogenic and can be produced to high titres and purity, all important considerations when developing such therapeutics for widespread clinical application.

\subsubsection{Adenovirus Cell Entry and Trafficking}

Human adenoviruses can be classified into seven species (termed A-G) comprised of over 100 serotypes [31]. Ads commonly infect the respiratory system however different serotypes can also infect the gastrointestinal, cardiac, neurological, ophthalmological and genitourinary tissues which can result in an array of clinical pathologies [32]. Ads bind to receptors on the membrane surface. Ad5 has been well described as recognising the coxsackievirus and adenovirus receptor (hCAR) [33]. Other receptors involved in adenoviral attachment are CD46 [34], desmoglein 2 (DSG2) [35] and sialic acid [36]. Primary receptor binding is dependent on the Ad serotype but generally species A, C, E and F interact with hCAR while species B and D utilise other receptors [37]. Species B is reported as using primarily CD46 and DSG2, and, although the individual receptors for many species D serotypes are unknown, it is thought there is sialic acid involvement [38,39]. Initial receptor attachment is followed by internalisation mediated by $\alpha v \beta 3 / 5$ integrin binding through a conserved Arg-Gly-Asp (RGD) motif [40]. Upon cell entry, the adenovirus is partially disassembled via endosome acidification and the uncoated is released and transports viral DNA into the nucleus [41]. Viral replication takes place in two phases: early phase and late phase. An overview of the adenoviral replication cycle is illustrated in Figure 2.

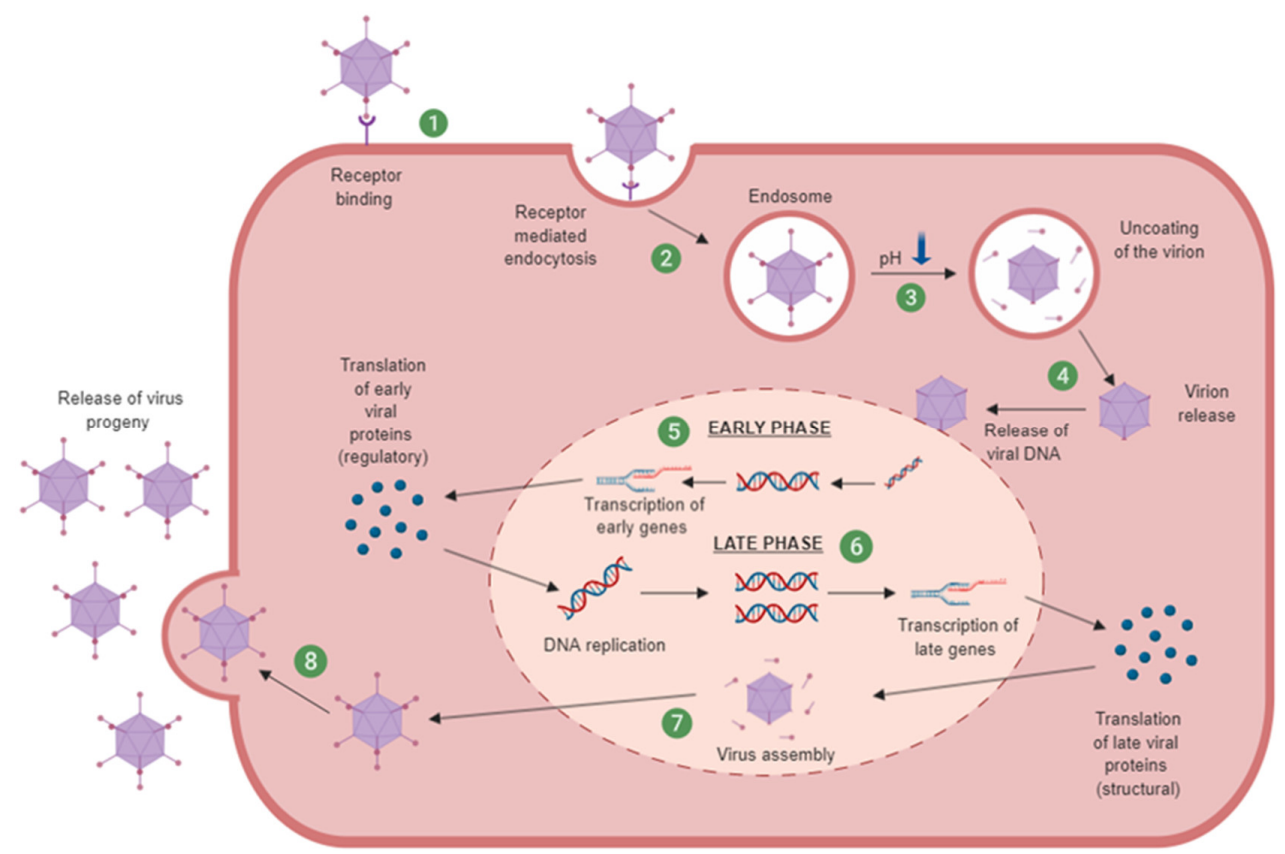

Figure 2. Adenovirus replication cycle. (1) Virus attachment to receptors on the host cell surface. (2) Internalisation of the virus by endocytosis. (3) Low $\mathrm{pH}$ results in endosomal acidification and partial disassembly of the virion. (4) Virion released from endosome and trafficked to the nuclear pore complex where it releases viral DNA into the nucleus. (5) Early phase: Transcription and subsequent translation of early genes to the regulatory early proteins. (6) Late phase: Transcription and subsequent translation of late genes to the late structural proteins. (7) Assembly of progeny virion. (8) Cell lysis resulting in release of mature virus. Created with https://biorender.com. Figure adapted from [41-44]. 


\subsubsection{Oncolytic Adenovirus}

Many Ad-based therapies in the clinic currently use replication-based control as a mechanism for cancer targeting. They are reliant on cancer selectivity at the point of cellular replication at a post cell entry stage rather than bona-fide tumour tropism. The concept that adenovirus infection mirrors several key hallmarks of cancer [45] underpins the mechanism that restricts the replication of many early oncolytic adenoviruses to tumour cells [46]. An oncolytic adenovirus that preferentially replicates in a tumour cell environment often takes advantage of genes that are frequently overexpressed in cancer. Deletion of viral replication genes to render the virus replication-incompetent in healthy cells, but replication proficient in tumour cells with dysregulated or inactivated tumour suppressor gene function $[47,48]$. These are termed replication selective oncolytic or conditionally replicating adenovirus $[49,50]$.

Adenovirus have many benefits for use as oncolytics. These include their relative ease of manipulation, being double stranded DNA viruses. Their capacity for transgene incorporation, being around $6 \mathrm{~kb}$ for non-replicating vectors and around $2 \mathrm{~kb}$ for oncolytic vectors is more than sufficient to encode therapeutic transgenes (or combinations of transgenes) to enhance the pro-immunogenic tumour microenvironment. These transgenes could include immune checkpoint inhibitors targeting PD-L1 or CTLA4 [51,52], cytokines such as TNF $\alpha$ and IL-2 [53] or chemokines including CCL5 [54]. Alternatively, genes encoding proteins that are directly cytotoxic to the tumour cells such as REIC/DKK-3 can also be incorporated [55].

Although early clinical data for many oncolytic viruses are encouraging, the exact mechanism of cell killing often remains unclear [56]. It is evident the viral and host cell interactions are complex, particularly in the context of systemic delivery and within the tumour microenvironment, and an understanding of the tumour and virus biology will provide insight and enhance future oncolytic virotherapies [57]. The popularity of adenovirus is evidenced by the sheer number of clinical trials, standing at 237 at the time of writing, that use adenovirus for cancer treatment in some form [58]. These trials have demonstrated safety and feasibility; however, delivery and efficacy must be improved if oncolytic adenovirus is to achieve its full promise as an effective cancer therapy $[59,60]$.

Despite their immense potential, adenoviruses, especially those based on the species $C$ serotype Ad5, have several pitfalls which need to be carefully addressed to tailor the OV in to an effective therapeutic. These disadvantages include the high rates of pre-existing immunity against Ad5 in the populations where Ad5 is a common pathogen. These levels of pre-existing immunity vary geographically from $>90 \%$ in sub-Saharan Africa [61] to $30 \%$ in the UK population [62]. High levels of pre-existing immunity will promote the rapid removal and destruction of the therapeutic by the reticuloendothelial system, resulting in limited bioavailability for active tumour targeting [63]. A further limitation stems from the native infectious routes via the capsid proteins of Ad5 that can also cause dose-limiting interactions and toxicity (Figure 3). The widespread anatomical expression of the primary receptor, Coxsackie and adenovirus receptor (hCAR) [33], means vectors based on Ad5 will be sequestered and infect a wide range of off target (non-cancerous) tissues in the body [64] or may become irreversibly trapped in the blood [65]. One way this can be overcome is by genetic modification of the amino acids 408 and 409 within the $\mathrm{AB}$ loop of the fibre knob protein (Fkn) to remove binding to hCAR (called the KO1 mutation) [66]. Although Ad5 predominantly uses hCAR there are alternative receptors utilised by other species including CD46 and desmoglein-2 (DSG-2) which are the primary entry route for Species B adenovirus [34,35]. The species B Ad3 pseudotype is a prominent oncolytic virus which uses both CD46 and DSG-2 for cell entry. CD46 is expressed on almost all nucleated cells, and DSG-2 is a cardiomyocyte [67] and tight junctions restricted receptor [68], and therefore present additional considerations for ablation of native binding tropisms. Species D does not appear to bind these three known adenoviral receptors with any significant affinity. There is evidence to suggest these viruses may be more likely to use sialic acid as their mode of entry $[36,37,69]$. 


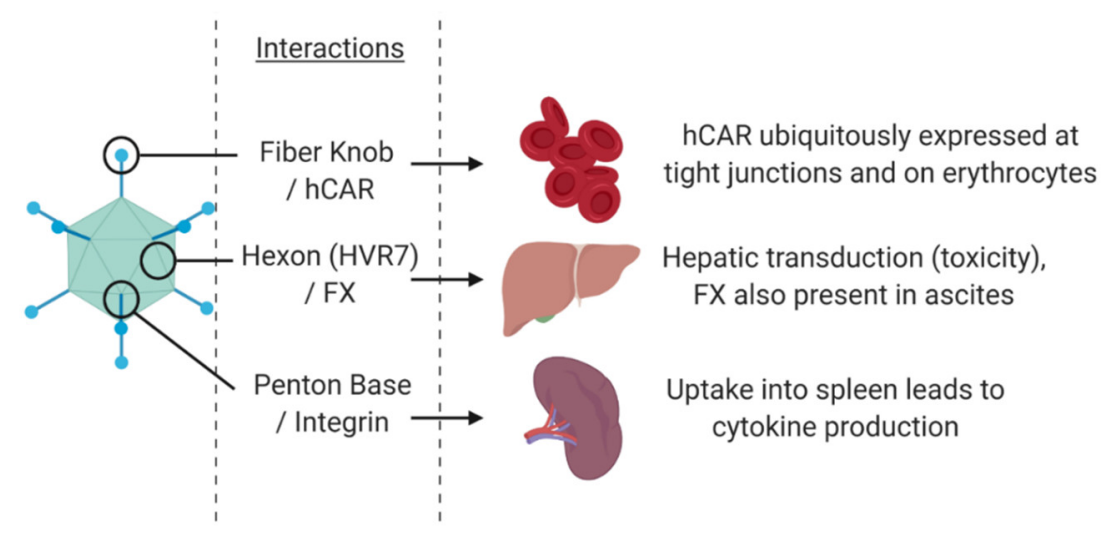

Figure 3. Dose-limiting Ad5 interactions in vivo. The fibre knob protein binds to hCAR expressed at tight junctions and on erythrocytes, the hexon binds to Factor X (FX) in the blood and the penton base binds to $\alpha v \beta 3 / 5$ integrins. These binding interactions would lead to off-target effects. Created with https://biorender.com.

Other capsid proteins can also cause off-target binding and sequestration issues. The hexon protein of Ad5 binds with high affinity to the blood clotting factor X (FX), which results in rapid and efficient transduction of hepatocytes, with consequent potential hepatotoxicity resulting from of Ad5 vectors [70,71]. The penton base protein on the capsid also has implications for off-target effects. The RGD domain in the pentameric protein group binds to integrins $\alpha \mathrm{v} \beta 3 / \alpha \mathrm{V} \beta 5$ leading to downstream signalling for internalisation [72]. These interactions are also thought to lead to uptake in the spleen inducing consequent pro-inflammatory responses against the Ad [73,74]. Therefore, mutation within the RGD binding region in the penton may be important in limiting these off-target effects [75].

In this review, we discuss the current approaches and significant refinements to the Ad5 capsid necessary to prevent off target interactions. We also consider alternative approaches to circumvent the Ad5 associated limitations and generate precisely guided cancer therapeutics.

\section{Genetic Engineering of Oncolytic Adenovirus}

The adenoviral genome is organised into early (E) and late (L) genes (Figure 4). The early phase genes encode proteins that regulate the host and viral proteins, avoid premature cell lysis and prepare components for DNA replication. Late phase produces structural proteins that are required for the assembly of mature virions [44].

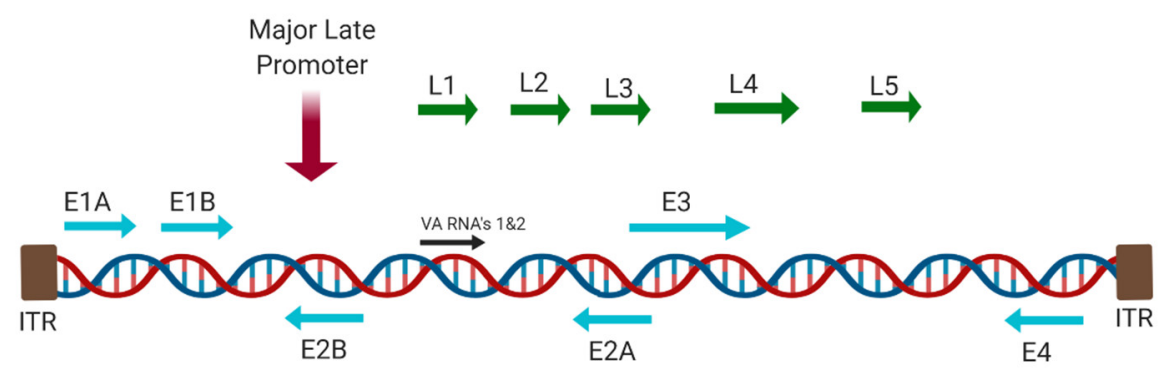

Figure 4. Adenoviral genome, highlighting key genes which are often modified or deleted in oncolytic therapeutics. Created with https://biorender.com.

The standard approach in the design of novel oncolytic virotherapies involves making modifications viral genes to improve cancer cell selectivity and oncolytic potency. The ability to engineer the double stranded DNA genome of adenovirus with relative ease has been proven for clinical applications from vectors for gene therapy and vaccines to oncolytic viruses [76]. A key feature in development of adenoviral vectors are the modifications to reduce the immunogenicity and bypass innate anti-viral immune responses. 
First generation adenoviral vectors harbour deletions in the E1 and E3 regions $[77,78]$. These deletions not only improved the vector safety profile but also create significant space necessary for the insertion of transgenes [79]. The E1 genes encode proteins necessary for viral replication, therefore E1 deletion results in a replication deficient virus [44]. Consequently, vectors with this deletion must be propagated in cell lines expressing E1 products in trans, such as 293 or PER.C6 cells [80-82]. E3 encoded viral proteins are involved in evading host antiviral immunity but are not essential for viral replication, deletion of this region allows insertion of larger genes but may reduce the oncolytic potency [83]. Second generation adenoviral vectors may also have the E2 and E4 regions deleted which eliminates expression of most Ad genes and allows more room for transgene insertion [84]. However, these vectors must be propagated in cell lines that express E1, E2 and E4 gene products. The late genes are involved in structure and therefore are required for production of mature virions. A final generation of Ad vectors that are lacking all viral coding regions have been developed. These are termed gutless or helper-dependent Ads as they require co-infection of a wild-type adenovirus or helper vectors [85]. These have promising therapeutic advantages but are difficult to manufacture in high quantities.

Conditionally replicating adenoviruses (CRAds) encompass several oncolytic adenovirus therapies in the clinic. They can be classified into two types, however both approaches involve modifications in the E1 region of the adenoviral genome. Adenovirus E1 is comprised of two genes: early region $1 \mathrm{~A}(\mathrm{E} 1 \mathrm{~A})$ and early region $1 \mathrm{~B}(\mathrm{E} 1 \mathrm{~B})$. E1A is the first transcribed gene post infection and promotes progression into S-phase of the cell cycle. E1B encodes genes that protect the cell from undergoing apoptosis as a result of E1A induction of $\mathrm{S}$ phase and enables the virus to undergo productive replication in the host cell. The first strategy employed when designing CRAds is to replace the E1 promotor with a tumour specific promotor, therefore preventing induction of E1A mediated viral replication in the absence of the appropriate promoter [86-88]. This approach can be used to restrict replication and to start the expression of the treatment transgenes within tumour cells. One example is the promotor survivin, which has been used to this effect, regulating the expression of the heat shock protein 70 (Hsp70) that inhibited tumour growth in gastric cancer and adult T-cell leukaemia (ATL) [86,89]. Another promotor of note is human telomerase reverse transcriptase promotor (hTERT). This promotor can enhance cell lysis, leads to increased release of viral progeny for further infection and shows reduced hepatocyte effects compared to ONYX-015 in solid tumour in-vivo models [90].

The second strategy relies on modifications within the E1 region preventing the virus from restricting host cell defences (for example, $\mathrm{pRb}$ mediated apoptosis) and therefore the virus is only able to replicate in tumour cells defective in these pathways. One of the most effective mutations described to date is the $\mathrm{dl} 24(\Delta 24)$ mutation. This mutation is a 24-base pair deletion in the constant region of E1A gene. This deletion is in the region that is responsible for binding the $\mathrm{Rb}$ protein and so targets replication to cells with abnormal $\mathrm{Rb}$ control that can bypass this pathway. This leads to selective replication in cells that are defective in the Rb/p16 pathway, which has been identified in the majority of cancers, including gliomas and ovarian cancers [91-94].

Another mutation used is the T1 mutation, which has a truncating insertion in the E3/19K protein. The T1 mutation means that this protein is relocated to the plasma membrane and enhances the release of virus from infected cells [95]. Therefore, this mutation may be a useful addition to a tumour-selective Ad-based therapy, such as in the oncolytic ORCA-010 [96].

\section{Current Clinical Applications of Oncolytic Adenoviral Therapies}

ONYX-015 (also referred to as $\Delta 1520$ ) was one of the first replication selective oncolytic adenoviruses tested in a clinical setting for the treatment of head and neck cancer $[97,98]$. ONYX-015 harbours an E1B55K deletion, which was originally thought to be essential for viral replication as it sequesters p53 and promotes cell cycle transition [99]. p53 is commonly lost or downregulated through mutations in multiple cancer cells [100], and it is therefore considered that ONYX-015 would replicate almost exclusively in cancer cells lacking p53. However, more recent 
research suggests that this mutation is more likely to work through the loss of late viral RNA export, rather than through p53 status alone. The mechanism of action may be more complex than originally thought, likely due to multi-modal action of the p53 pathway $[49,101,102]$. Whilst ONYX-015 and a variant H101 (E1B55K and E3 deletion) demonstrated the safety of oncolytic adenoviruses, the efficacy was limited by attenuated viral replication and spread [96,103]. Subsequent generations of tumour selective oncolytic adenoviruses contain mutations in the E1A gene that functions through binding the retinoblastoma protein $(\mathrm{pRb})$ [91]. Several oncolytic adeno-virotherapies have since entered clinical trials (Table 1) and have demonstrated safety and feasibility. However, delivery and efficacy must be improved if oncolytic adenovirus is to be used as an effective cancer therapy, especially as a systemically administered agent capable of effectively targeting tumours and metastases $[59,60]$.

The vast majority of adenovirus research to date has focused on the species C, Ad5. Several oncolytic adenoviruses (OAds) have demonstrated limited efficacy in clinical trials as a result of poor viral persistence [104,105]. Although this is, in part, related to the early design of these viruses, it may also result from high levels of pre-existing immunity [106]. A substantial proportion of the population will have experienced an acute adenovirus infection, and many will have developed neutralising antibodies against the most common Ad serotypes [32]. Activation of anti-tumour immunity whilst dampening the innate host anti-viral immune response is essential to the success of OAds. An alternative approach, therefore, may be through the development of alternative, low seroprevalence adenoviral species, such as those from Species B or D, which tend to have naturally low levels of pre-existing immunity in the population [107]. Such serotypes may also exhibit naturally lower levels of off target uptake due to reduced interactions with components of the blood. Ad5 is known to bind to FX in serum which mediates sequestration by the liver and can impact virus delivery to the tumour [108]. FX binds the hexon protein on Ad5 capsid and can result in off target uptake [109]. It was observed that alternative species, for example species D Ad26, does not bind FX in the same manner as Ad5 [109]. This knowledge was used to identify key residues in FX binding through sequence alignment and has fed into the production of retargeted Ad vectors however the use of alternative species as an alternative to Ad5 has not been fully explored [71]. The use of novel oncolytics developed from rarely isolated serotypes from species D may represent an exciting and alluring possibility, where the diverse nature of this species represents a significant and largely untapped repository for investigation. Recent significant progress has been made in this regard by the Ehrhardt laboratory, who have investigated a larger spectrum of adenoviral vectors and begun to evaluate their potential for oncology applications [110,111].

Alternative adenoviral species offer many advantages over the commonly used Ad5-based therapies however, despite their increasing popularity as platforms for vaccine applications, they are poorly represented in the clinical oncology setting. Ad5/kn3 pseudotype has demonstrated some limited efficacy in ovarian cancer $[112,113]$. This targets via species B receptors which are not cancer specific and maintain the previously outlined issues associated with Ad5-based vectors. 
Table 1. A summary table of Ads in clinical trials, with their base genome, modifications and their target. Data obtained from https://www.cancer.gov/ (Accessed on: 30 October 2020).

\begin{tabular}{|c|c|c|c|c|c|}
\hline Biologic & Synonyms & Adenovirus genome & Modifications & 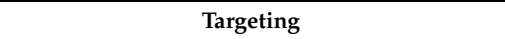 & NCI Identifier \\
\hline $\begin{array}{l}\text { GM-CSF-encoding Oncolytic } \\
\text { Adenovirus CGTG-102 }\end{array}$ & ONCOS-102 & $\begin{array}{l}\text { Adenovirus serotype 5/3 } \\
\quad \text { (capsid-modified) }\end{array}$ & $\begin{array}{l}\text { Ad5 capsid protein replaced with Ad3 knob domain. } \\
\text { Granulocyte-macrophage colony stimulating factor } \\
\text { (GM-CSF) }\end{array}$ & $\begin{array}{l}\text { Selective replication in } \mathrm{Rb} / \mathrm{p} 16 \text { defective cells. } \\
\qquad \mathrm{Ad} 3 \text { receptors. }\end{array}$ & C98287 \\
\hline $\begin{array}{l}\text { OX40L-expressing Oncolytic } \\
\text { Adenovirus DNX-2440 }\end{array}$ & $\begin{array}{l}\text { Oncolytic Adenovirus Armed } \\
\text { with OX40L DNX-2440 }\end{array}$ & Adenovirus serotype 5 & Expresses OX40 ligand (OX40L). $\Delta 24$ mutation & Selective replication in $\mathrm{Rb} / \mathrm{p} 16$ defective cells & C160192 \\
\hline \multirow{2}{*}{ Oncolytic Adenovirus ORCA-010 } & Modified Ad5 ORCA-010 & \multirow{2}{*}{$\operatorname{Ad} 5 / 3$} & \multirow{2}{*}{$\begin{array}{l}\Delta 24 \text { mutation. RGD-4C motif. T1 mutation in } \\
\text { E3/19K gene }\end{array}$} & \multirow{2}{*}{$\begin{array}{l}\text { Selective replication in } \mathrm{Rb} / \mathrm{p} 16 \text { defective cells. T1 } \\
\text { mutation enhances Ad5 release, Ad3 receptors }\end{array}$} & \multirow{2}{*}{ C168607 } \\
\hline & Oncolytic Adenovirus ORCA-010 & & & & \\
\hline $\begin{array}{l}\text { Oncolytic Adenovirus Encoding } \\
\text { GM-CSF }\end{array}$ & CG0070 & Adenovirus serotype 5 & $\begin{array}{l}\text { E2F-1 promotor. Granulocyte-macrophage colony } \\
\text { stimulating factor (GM-CSF) in E3 region }\end{array}$ & Selective replication in $\mathrm{Rb} / \mathrm{p} 16$ defective cells & C48412 \\
\hline Delolimogene Mupadenorepvec & $\begin{array}{l}\text { Double-armed } \\
\text { TMZ-CD40L/4-1BBL Oncolytic } \\
\text { Ad5/35 Adenovirus LOAd703 }\end{array}$ & $\begin{array}{l}\text { Adenovirus serotype } 5 \text { with L5 } \\
\text { segment of fiber replaced with } \\
\text { Ad35 fiber }\end{array}$ & Expresses trimerized CD40 ligand. $\Delta 24$ mutation in E1A & $\begin{array}{l}\text { Targets } \mathrm{CD} 46 \text {. Selective replication in } \mathrm{Rb} / \mathrm{p} 16 \\
\text { defective cells }\end{array}$ & C148462 \\
\hline $\begin{array}{l}\text { Oncolytic Adenovirus } \\
\text { ICOVIR5-infected Autologous } \\
\text { Mesenchymal Stem Cells }\end{array}$ & LOAd 703 & Wildtype human adenovirus 5 & $\begin{array}{l}\text { RGD-4C motif allows integrin binding. } \Delta 24 \text { in E1A } \\
\text { prevents Rb complex and transition into } S \text { phase }\end{array}$ & $\begin{array}{l}\text { Bone marrow-derived MSCs target and deliver } \\
\text { adenovirus to tumour }\end{array}$ & C107160 \\
\hline \multirow{3}{*}{ Tasadenoturev } & DNX-2401 & \multirow{3}{*}{ Adenovirus serotype 5} & \multirow{3}{*}{$\begin{array}{l}\text { RGD-4C motif allows integrin binding. } \Delta 24 \text { in E1A } \\
\text { prevents } \mathrm{Rb} \text { complex and transition into } \mathrm{S} \text { phase }\end{array}$} & \multirow{3}{*}{$\begin{array}{l}\text { CAR independent. Selective replication in } \\
\mathrm{Rb} / \mathrm{p} 16 \text { defective cells }\end{array}$} & \multirow{3}{*}{ C74067 } \\
\hline & $\begin{array}{l}\text { (Oncolytic Adenovirus) } \\
\text { Ad5- } \Delta 24 \text { RGD }\end{array}$ & & & & \\
\hline & $\begin{array}{l}\text { Oncolytic Adenovirus } \\
\text { Ad5-DNX-2401 }\end{array}$ & & & & \\
\hline \multirow{3}{*}{$\begin{array}{l}\text { Tasadenoturev-infected } \\
\text { Allogeneic Bone Marrow-derived } \\
\text { Mesenchymal Stem Cells }\end{array}$} & $\begin{array}{l}\text { Ad5-DNX-2401-infected } \\
\text { Allogeneic Bone Marrow } \\
\text { Mesenchymal Stem Cells }\end{array}$ & \multirow{3}{*}{ Ad5-DNX-2401 } & \multirow{3}{*}{$\begin{array}{l}\text { RGD-4C motif, } \Delta 24 \text { in E1A prevents Rb complex and } \\
\text { transition into } S \text { phase }\end{array}$} & \multirow{3}{*}{$\begin{array}{l}\text { Bone marrow-derived MSCs target and deliver } \\
\text { adenovirus to tumour }\end{array}$} & \multirow{3}{*}{ C159798 } \\
\hline & (Allogeneic) BM-hMSC- $\triangle 24$ & & & & \\
\hline & (Allogeneic) BM-hMSC- $\Delta 24-R G D$ & & & & \\
\hline Ad5-yCD/mutTKSR39rep-hIL12 & $\begin{array}{l}\text { Oncolytic Adenovirus } \\
\text { Ad5-yCD/mutTKSR39rep-hIL12 }\end{array}$ & Adenovirus serotype 5 & $\begin{array}{l}\text { Encodes murine interleukin-12 (IL-12) gene in E3 region } \\
\text { and a suicide fusion gene (yCD/HSV-1 TKSR39) in E1 } \\
\text { region }\end{array}$ & E1B55K deletion & C123930 \\
\hline \multirow{2}{*}{ Enadenotucirev } & ColoAd-1 & \multirow{2}{*}{$\begin{array}{l}\text { Chimeric Oncolytic Adenovirus } \\
\text { Ad3/Ad11p }\end{array}$} & \multirow{2}{*}{$\begin{array}{l}\text { Deletions in E3 Region (2444 bp) and E4 Region (24 bp) } \\
\text { and } 197 \text { Non-homologous nucleotides in the E2B Region }\end{array}$} & \multirow{2}{*}{ Not fully understood } & \multirow{2}{*}{ C113786 } \\
\hline & EnAd & & & & \\
\hline
\end{tabular}


Species B adenovirus have demonstrated the potential to play an important role in the field of adenoviral oncolytics. An alternative strategy to the rational development of novel Ad serotypes for oncology applications has been to develop a novel chimeric OV through a process of natural selection for recombinants with enhanced cell killing activity in cancer cells such as with enadenotucirev (EnAd, formally known as ColoAd1; PsiOxus Therapeutics Ltd., Abingdon, UK). Several adenovirus serotype recombinants were selected for on colon cancer cells (HT29) by this method of "directed evolution" (Figure 5) [114]. Despite the initial pool representing diverse serotypes from species B-F, the resultant chimera is a fully species B recombinant, derived from Ad11p and Ad3 [114]. This virus demonstrated potency and selectivity greater than ONYX-015 and Ad5 [115]. The tumour selectivity mechanism for EnAd is not fully understood however initial clinical trials have demonstrated durability and tolerability, not only for colorectal cancers but with other solid cancers [115,116]. EnAd is thought to act through a non-apoptotic mechanism termed ischemic cell death and possesses pro-inflammatory properties [117]. Species B therefore represents an exciting avenue for development of oncolytics, however the lack of intrinsic tumour specificity and high prevalence of species B receptors, CD46 and DSG-2, on healthy cells is an important consideration that may result in the depletion of virotherapy available for active targeting of tumours through off-target sequestration. Ablation of these native interactions or use of Ads that bind receptors with weak affinity may result in improved novel retargeted oncolytics.

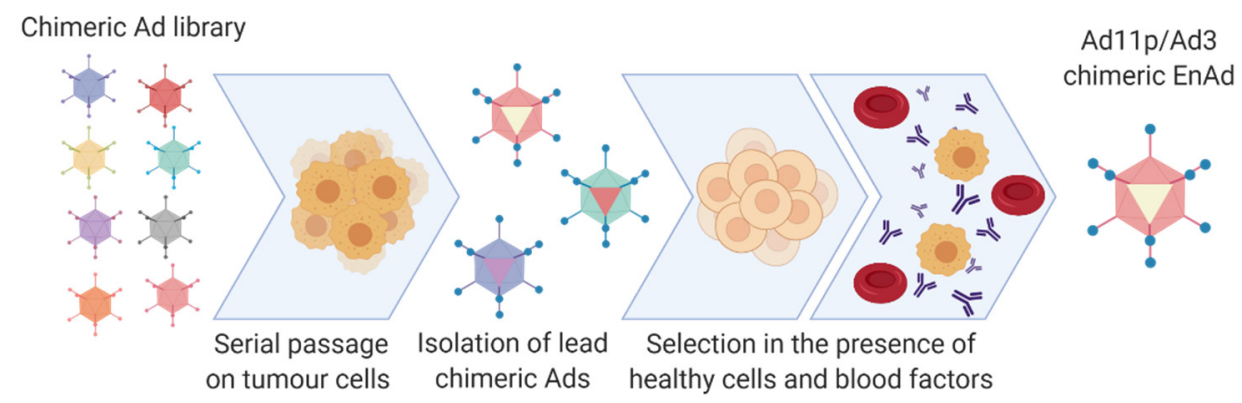

Figure 5. Method of production for oncolytic virus, EnAd (PsiOxus Therapeutics Ltd., Abingdon, UK). Serial passages of an Adenoviral library in tumour cells lead to chimeric Ads development. Selection with healthy cells and blood factors removes those that bind off-target receptors, lead to Ad11p/Ad3 chimeric EnAd being selected for. Created with https://biorender.com.

\section{Detargeting Ads}

Adenovirus has not evolved as a cancer selective pathogen, and therefore requires engineering in order to effectively target cancer cells. In Ad-based therapies, the efficiency of the treatment can be greatly affected by their native binding interactions. The most studied Ad, Ad5, binds hCAR which localises to the tight junctions between cells and is expressed ubiquitously throughout the body [33,118]. hCAR has also been reported as downregulated in certain cancers [119-121]. Therefore, reliance upon hCAR as an entry receptor for any Ad-based cancer therapy would greatly limit its uses, as transduction would be limited to cancer cells with high-hCAR expression, and off-target transduction could lead to tissue toxicity. Moreover, more aggressive cancer growth correlates with loss of hCAR expression, and so non-targeted Ad therapy is unlikely to treat aggressive cancers through hCAR transduction alone [118].

hCAR binding can be ablated by mutating the key amino acids in the fibre knob AB loop (L5 gene), using the KO1 mutations, S408E and P409A [66,122]. hCAR mediated cell entry is a two-step mechanism. First the virus attaches to hCAR and, secondly the virion internalised through binding of an Arg-Gly-Asp (RGD) motif in the penton base to $\alpha v \beta 3 / \alpha v \beta 5$ transmembrane integrins on the cell surface [123]. This secondary interaction has been exploited to further detarget Ad5 through the RGD to RGE modification of the penton base and improve cancer targeting. The Ad5 $5_{\text {NULL vector }}$ encompasses the KO1 mutation, the RGD to RGE modification as well as a modification within 
the hexon hypervariable region (HVR7) in order to ablate binding to coagulation FX and prevent sequestration by and transduction of liver hepatocytes [13,124].

Larger modifications can also be made to detarget the virus particle, such as replacing the fibre shaft of Ad5 with shorter variations found in other serotypes such as Ad40, or Ad41. This approach has shown reduced binding to cells [125-127].

Chemical modifications can also be used as a means of detargeting through polymer coating of the Ad particle. Polyethylene glycol (PEG) is commonly used for this purpose, due to its cationic properties [128]. The main advantage of coating the Ad is to prevent neutralisation by pre-existing antibodies which reduces the efficiency in patients previously exposed to the Ad. The use of chemical modifications was well reviewed elsewhere previously by Kreppel and Kochanek [129] and Kim et al. [130]. A major disadvantage of non-genetic means of targeting is that daughter virions produced through replication will not harbour the modifications necessary to target tumour cells, and therefore genetic strategies which are heritable are therefore more commonly preferred.

\section{Retargeting Strategies}

Here, a range of retargeting strategies is discussed, and both CRAds and oncolytic virus results are considered in this section together. This is due to the abilities of the targeting strategies to be applied in either context.

\subsection{Pseudotyping}

One relatively common method to introduce new tropism to an Ad-based therapeutic is to use chimeric fibre knob/shaft proteins through pseudotyping. Pseudotypes are recombinant adenoviruses that combine different aspects and structural proteins from differing serotypes into a chimera, and are often generated to cherry pick optimal features associated with different serotypes [131]. This genetic strategy uses Fkn (fibre knob) proteins from less-commonly used Ad species that do not use hCAR as a primary transduction mechanism and substituting these onto an OV based on Ad5. This confers new binding abilities without having to move away from the large knowledge base of commonly used Ad5. This has shown some success in colon cancer [132] and ovarian cancer [133] amongst others.

The use of chimeric Fkns (cFkns) has been extended by sequences from non-human Ad species [134] and through chimeric fibres created from several sequences such as bacteriophage $\mathrm{T} 4$ fibritin and human CD40 ligand (CD40L) in conjunction with the Ad5 Fkn [15].

Pseudotyping can also be used for the whole fibre protein comprising both the shaft and knob domain into the Ad5 capsid. However, the "tail domain" is an important consideration in this strategy, as the maintenance of a portion of the N-terminus of the parent fibre shaft is required for the translation of binding to the penton base of the parental capsid [135]. Shayakhmetov and Lieber demonstrated that pseudotyping the fibre proteins can also alter the binding capabilities of the virus. Pseudotyping the fibre shaft and the Fkn proteins from Ad5, Ad9 and Ad35 results in different receptor usage and intracellular trafficking, partly down to the length and geometry of the fibre shaft [136].

Though this method has shown promising results, it has its limitations. Creating a chimera that can correctly fold once it is attached to the fibre shaft can be a limitation in itself. The cFkn formed and its binding capabilities are likely dependent on its ability to form trimers, which is required for native Ad binding [137]. If such a protein is found that can correctly fold once attached to the fibre shaft, and form the trimers required for binding, it then must confer a novel binding tropism. The natural array of binding tropisms already understood from the less-commonly studied Ad species that can be pseudotyped is limited. Therefore, although this method has its place as a tool for investigating the tropism of rarely isolated adenoviral species, other mechanisms may prove more useful in the context of developing tumour tropism. 


\subsection{Peptide Retargeting}

One mechanism employed experimentally to enhance hCAR independent uptake of Ads into cells is to enhance targeting to upregulated $\alpha \mathrm{v} \beta 3 / 5$ integrins on tumour cells. The most successfully deployed has been the RGD-4C motif, incorporated into the HI loop of the fibre knob, which has demonstrated improved uptake in cancers expressing high levels of integrins such as ovarian cancer and glioma $[138,139]$. This modification enables suitable presentation of the integrin interacting RGD motif, held in position by the pair of disulphide bonds between the cysteine residues, to successfully engage with cellular integrins and stimulate uptake via endosomes.

Other retargeting methods have also proven effective, such as insertion of peptide sequences which confer a known binding ability within the Fkn protein, though this comes with its own limitations. The sites within the Ad5 fibre knob domain in which peptide sequences can be inserted successfully have been narrowed down through structural studies, demonstrating the HI loop and the C-terminus of the protein as the most promising sites [123,140]. Within other serotypes, hypervariable nature of the loops within the fibre knob protein have demonstrated that other loops are more surface exposed and thus better suited to genetic insertions, for example the DG loop in Ad48 has been shown to be the region best suited to genetic manipulation [141,142]. Insertions in these sites have shown promising results in targeting Ads, such as targeting towards ovarian, breast and prostate cancer cell lines by insertion of Her2/neu-reactive Affibody into the HI loop of a native-binding ablated Ad5 vector $[143,144]$.

Peptide sequences from other viruses had also been shown to target an Ad-based therapy towards cancer cells. Insertion of a 20-aa peptide, NAVPNLRGDLQVLAQKART, native to foot and mouth disease virus (FMDV) was identified as a binding peptide sequence to $\alpha \mathrm{v} \beta 6$ integrin [145], an integrin that is reported to be upregulated in certain epithelial cancers, including breast, ovarian, pancreatic and colorectal [146-148]. Figure 6 illustrates the Ad5 fibre knob protein engineered to present the A20 peptide within the HI loop in complex with $\alpha v \beta 6$ integrin. This peptide has previously been studied in terms of cancer research, used for non-invasive radiolabelled peptide for cancer imagery, whilst antibodies and CAR-T cells directed to $\alpha \mathrm{v} \beta 6$ integrin are also being investigated, underpinning the potential of this biomarker for cancer selective targeting $[145,149,150]$. The A20 peptide has been successfully incorporated into the $\mathrm{Ad} 5_{\mathrm{NULL}}$ to create the $\mathrm{Ad} 5_{\mathrm{NULL}}-\mathrm{A} 20 \mathrm{OV}$, which is a highly selective virotherapy targeting ovarian cancer [13], and with significant promise to target other epithelial cancers expressing high levels of $\alpha v \beta 6$ integrin.

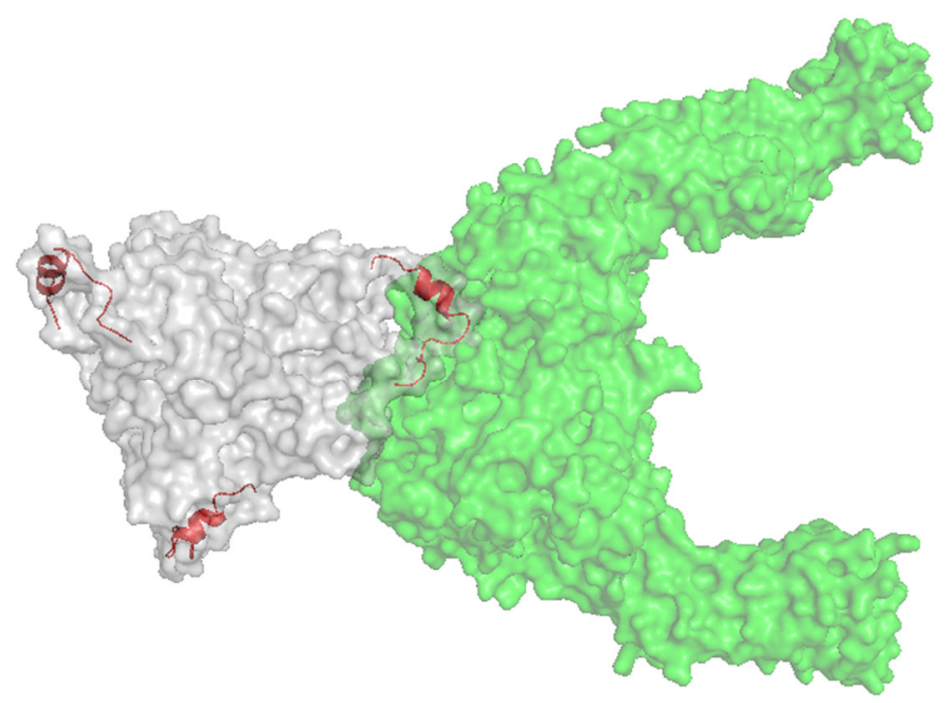

Figure 6. Ad5 knob (white) with the A20 peptide insertion (red) in complex with $\alpha \mathrm{v} \beta 6$ (green). Image created using PyMol. 
Other sites in the capsid that are amenable to insertions have also been explored, such as the hexon gene. Insertion into the hexon has good potential for targeting due to its abundance in the capsid. If all copies displayed the insertion, it could lead to a coated Ad capsid with 720 copies of the targeting peptide. This has shown some recent success, through insertion of muscle binding peptides into the hypervariable region 4 (HVR4) in the hexon protein [14], as well as the RGD-4C peptide [151,152].

When modifying viral capsid proteins, additional considerations should be made. The size, structure and charge of the insert can affect its success due to steric hindrances. The rate-limiting step is the lack of efficacious tumour targeting peptides that can be incorporated into the viral capsid efficiently to retarget towards cancer cells with limited off-site effects.

Targeting peptides which have proven effective when presented within the context of the three-dimensional fibre knob protein often appear to be those which have a degree of secondary structure. The secondary structure is important to consider as strategies using linear peptides have proven to be less successful. For example, the RGD-4C peptide is designed to present the RGD integrin interacting tripeptide at the apex of the loop, held in place by disulphide linkages. Similarly, the A20 peptide forms an alpha helical confirmation both in its native context within the vp1 protein of FMDV, which it retains when transferred into the Ad5 fibre knob protein, thus retaining the geometry required for receptor engagement. For future targeting strategies to be successful, it will likely require the development of sophisticated molecular technologies, capable of high throughput evolution, screening and selection of knob variants with increased binding affinity for tumour associated antigens of interest.

\subsection{Techniques for Targeting Peptide Discovery}

Other methods for retargeting Ads have also had some success. Despite the success of Ad5 $5_{\mathrm{NULL}}-\mathrm{A} 20$, there has been limited continued success using the Ad5 $5_{\text {NULL }}$ platform to target other tumour-associated antigens (TAAs) and receptors. The rate-limiting step is the lack of efficacious tumour targeting peptides that can be incorporated into the viral capsid efficiently to retarget the Ad5 $5_{\text {NULL }}$ platform towards tumour cells. Previously, we and others have utilised methods such as bacteriophage (phage) biopanning to identify peptides that can bind TAAs [153-155].

Biopanning is an approach that uses affinity-based selection. Random peptide libraries can be created and displayed on the phage, often in the pVII or pIII gene of filamentous phage M13 (Figure 7). M13 has around 5 copies of each $\mathrm{pVII} / \mathrm{pIII}$ gene products in the capsid, located at the end of the cylindrical phage. The resultant library is incubated with a target protein (or cell line), allowing binding to occur. Unbound phage, or those with low affinity, are then washed away. Finally, those random peptides still bound strongly to the target are eluted, either by changing the $\mathrm{pH}$ or by competitive inhibition. The process is repeated to identify peptides with the highest affinity for the given target, which can be sequenced for further use [156]. Phage display allows for high throughput analysis of peptide libraries for targeting a specific receptor protein. In fact, this method has been used frequently, with peptides targeting EGFR [157] and HER2 [158]. Promising peptides can be inserted into the permissive regions of Ad5 Fkn [155]. This has been tried with several different peptides targeting cancer-specific markers, such as folate receptor $\alpha(\mathrm{FR} \alpha)$ commonly upregulated in ovarian cancers [159]. However, after binding, the FR $\alpha$ mediated cell entry mechanism does not allow for correct intracellular trafficking, showing retention of targeted virotherapies in late endosomes in FR $\alpha$ positive ovarian cancer cells, with limited successful transduction [153]. This highlights another potential consideration when developing targeting approaches for adenoviral-based oncolytics-not all TAA receptor pathways will be compatible with clathrin-mediated endocytosis pathways and thus represent viable entry routes for adenoviral-based virotherapies. 

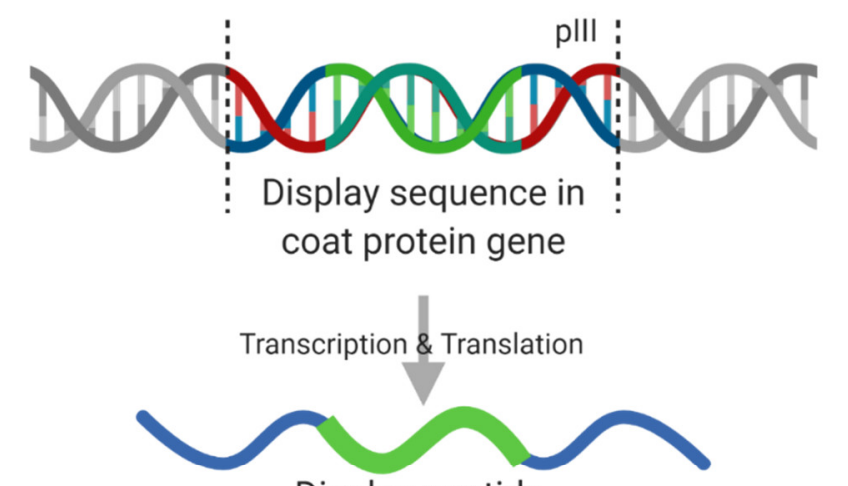

Display peptide

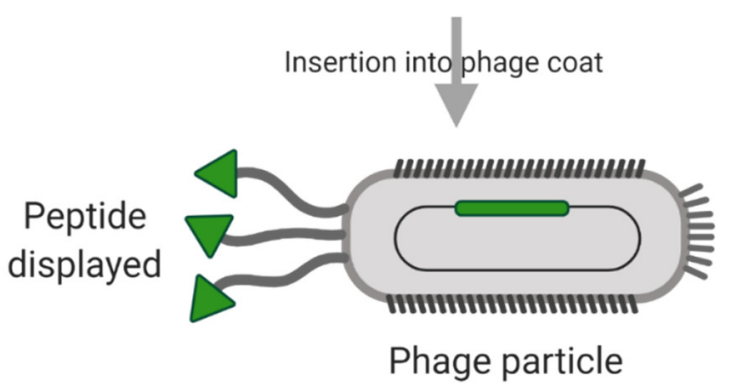

Figure 7. M13-based phage display mechanism. Created with https://biorender.com.

Additional limitations to this approach revolve around the linear orientation of the peptides being selected and displayed. Although promising peptides can be found through this approach, once they are incorporated back in the Fkn, the peptide can change confirmation due to the three-dimensional nature of the viral capsid protein into which the peptide is engineered. It could be assumed that the difference, and therefore the success, of the A20-peptide is due to the constrained orientation was maintained. A20 was identified in FMDV and transposed into Ad, and thus the orientation was conferred. Conversely, in phage-display technology, the selection is based around incorporation into the capsid coat proteins in a linear orientation.

A secondary issue of note for the future of this technology is that insertions can only be made in one linear string of DNA, creating one addition to the coat proteins in the phage particle to be used in selection. For this technology to be the answer to extending the use of OAds to many different cancer types, with very different surface protein expression profiles, there needs to be a way of incorporating, and thus selecting for, multiple regions that confer binding but are not next to each other in linear DNA sequence. This would create additional problems such as the requirement for multiple incorporation sites in the Ad Fkn protein and the complexity of maintaining the correct confirmation of these multiple sites in protein space (for example, distance apart on the Fkn, interactions with polar amino acids nearby limiting availability for binding and flexibility of the insert). However, if these were to be achieved, it would allow for quick, efficient and effective selection of cancer-specific binding peptide regions for incorporation into an Ad-based vector.

Lupold et al. also developed a useful technique for retargeting, using the Ad particle itself. The pTex system uses a similar approach to pseudotyping mixed with peptide insertions, but allowing isolated and randomised mutation of the fibre knob for later incorporation into the capsid. This system overcomes some of the issues, such as linear display, although it may be limited for targeting towards a specific receptors of interest without the issue of previously understood peptide-ligand interactions [160].

The detargeting and retargeting methods highlighted in this review are overviewed in Figure 8. 
Methods for overcoming limitations and improving tumour-selection

Detargeting

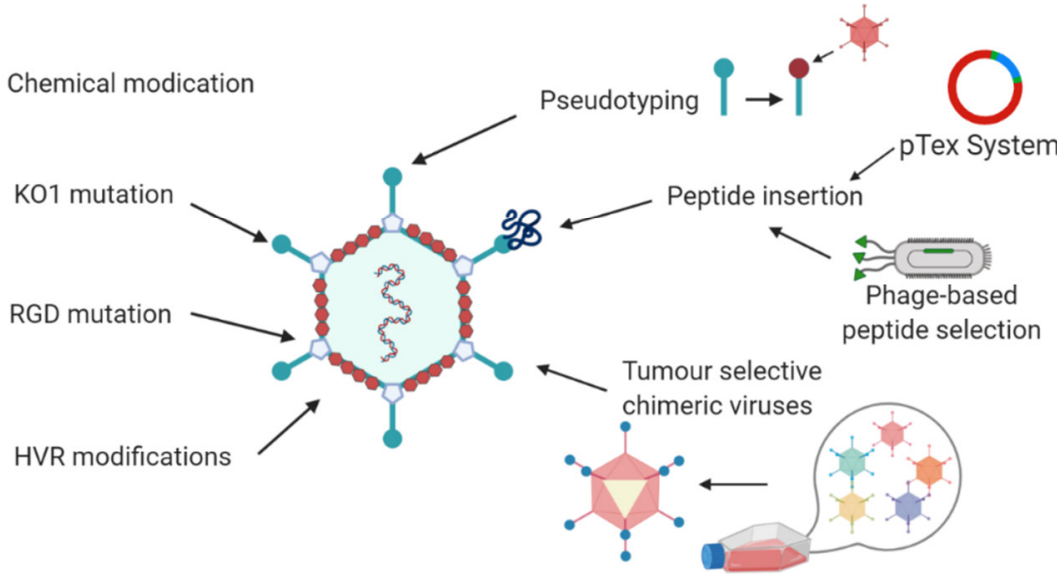

Figure 8. Overview of putative adenoviral detargeting and retargeting approaches. Created with https://biorender.com.

\section{Conclusions}

Oncolytic adenoviruses are powerful therapeutic agents with great potential in the clinical arena, combining multiple cell-killing effects on the tumour microenvironment. Firstly, the life cycle of adenovirus induces immunogenic cell death. Moreover, the process of replication and lysis results in the production of many tens of thousands of additional daughter virions, which when released, infect surrounding cells, thus repeating and amplifying the process. Additional engineering of the viral genome to encode therapeutic transgenes, such as immunotherapies, cytokines or pro-apoptotic proteins can further enhance the immunogenicity of the tumour microenvironment effectively turning the tumour into a factory producing protein to promote its own destruction.

Despite some early evidence of efficacy as a combination therapy in the clinic, the development of fully refined oncolytic adenoviruses has failed to reach its full potential. There are numerous obstacles to sequentially consider when developing novel adenovirus based oncolytic virotherapies, including infection of non-cancerous cells, activation of the anti-viral immune response and a limit in the number of viruses with native cancer tropism. The ability to modify the adenoviral genome and overcome these limitations makes them attractive candidates for targeted oncolytic virotherapies. Furthermore, there is a vast repository of alternative adenoviral serotypes, possessing known advantages over Ad5-based therapies, that are yet to be explored in an oncology setting. Employing techniques such as peptide insertion has had promising pre-clinical results and if combined with additional modifications to further detarget and arm with therapeutic transgenes, the result would be highly potent targeted oncolytic virotherapies. Whilst significant progress has been made in developing such systems (e.g., the Ad5 NULL platform), step changing technologies will be required to develop optimally targeted "precision virotherapies" to tumour specific molecular addresses, and thus to deliver truly personalised virotherapies moving forwards.

Therefore, the remaining limitations for targeted oncolytic applications using this approach are the identification of ligands that are cancer-specific [161], coupled with the poor ability to transfer linearly selected peptides from phage libraries into the three-dimensional Ad structure. In a sense, whilst technologies exist to elucidate peptides or antibody fragments that allow us to "hit" tumour targets of interest, the success of such targeting technologies when translated into oncolytic virotherapies will require smarter systems, designed to engineer tropisms directly into the viral capsid protein of relevance to be successful, or else they will continue to "miss the point". Developing technologies deigned to overcome these limitations will be key to the future success and efficacy in the clinic. 
Funding: TGC is funded by Knowledge Economy Skills Scholarships (KESS 2) PhD studentship to ALP: 515374, EAB is funded by a Cardiff University School of Medicine PhD award to ALP (AC1170AP02). ALP is funded by HEFCW.

Conflicts of Interest: The authors declare no conflict of interest.

\section{References}

1. Cancer Research UK. Cancer Survival Statistics|Cancer Research UK. Available online: https://www. cancerresearchuk.org/health-professional/cancer-statistics/survival (accessed on 23 April 2019).

2. Yan, L.; Rosen, N.; Arteaga, C. Targeted cancer therapies. Chin. J. Cancer 2011, 30, 1-4. [CrossRef] [PubMed]

3. Arteaga, C.L. Trastuzumab, an appropriate first-line single-agent therapy for HER2-overexpressing metastatic breast cancer. Breast Cancer Res. 2003, 5, 96-100. [CrossRef] [PubMed]

4. Eiger, D.; Pondé, N.F.; De Azambuja, E. Pertuzumab in HER2-positive early breast cancer: Current use and perspectives. Futur. Oncol. 2019, 15, 1823-1843. [CrossRef] [PubMed]

5. Vogel, C.L.; Cobleigh, M.A.; Tripathy, D.; Gutheil, J.C.; Harris, L.N.; Fehrenbacher, L.; Slamon, D.J.; Murphy, M.; Novotny, W.F.; Burchmore, M.; et al. Efficacy and Safety of Trastuzumab as a Single Agent in First-Line Treatment of HER2 -Overexpressing Metastatic Breast Cancer. J. Clin. Oncol. 2002, 20, 719-726. [CrossRef]

6. Lv, S.; Wang, Y.; Sun, T.; Wan, D.; Sheng, L.; Li, W.; Zhu, H.; Li, Y.; Lu, J. Overall Survival Benefit from Trastuzumab-Based Treatment in HER2-Positive Metastatic Breast Cancer: A Retrospective Analysis. Oncol. Res. Treat. 2018, 41, 450-455. [CrossRef]

7. Ivy, S.P.; Wick, J.Y.; Kaufman, B.M. an overview of small-molecule inhibitors of VegFr signaling. Nat. Rev. Clin. Oncol 2009, 6, 569-579. [CrossRef]

8. Samson, A.; Scott, K.J.; Taggart, D.; West, E.J.; Wilson, E.; Nuovo, G.J.; Thomson, S.; Corns, R.; Mathew, R.K.; Fuller, M.J.; et al. Intravenous delivery of oncolytic reovirus to brain tumor patients immunologically primes for subsequent checkpoint blockade. Sci. Transl. Med. 2018, 10, eaam7577. [CrossRef]

9. Bourgeois-Daigneault, M.-C.; Roy, D.G.; Aitken, A.S.; El Sayes, N.; Martin, N.T.; Varette, O.; Falls, T.; St-Germain, L.E.; Pelin, A.; Lichty, B.D.; et al. Neoadjuvant oncolytic virotherapy before surgery sensitizes triple-negative breast cancer to immune checkpoint therapy. Sci. Transl. Med. 2018, 10, eaao1641. [CrossRef]

10. Chawla, S.P.; Chua, V.S.; Kim, K.; Dy, P.S.; Paz, M.K.; Angel, N.; Wang, K.; Moradkhani, A.; Quon, D.; Wong, S.; et al. The TNT protocol: A phase II study using talimogene laherparepvec (TVEC), nivolumab (N) and trabectedin $(\mathrm{T})$ as first, second/third line therapy for advanced sarcoma, including desmoid tumor and chordoma. J. Clin. Oncol. 2020, 38, TPS11572. [CrossRef]

11. ClinicalTrials.gov. Talimogene Laherparepvec and Pembrolizumab in Treating Patients With Stage III-IV Melanoma-Full Text View-ClinicalTrials.gov. Available online: https://clinicaltrials.gov/ct2/show/ NCT02965716 (accessed on 28 October 2020).

12. ClinicalTrials.gov. Ipilimumab, Nivolumab, and Talimogene Laherparepvec Before Surgery in Treating Participants With Localized, Triple-Negative or Estrogen Receptor Positive, HER2 Negative Breast Cancer-deleted-Full Text View-ClinicalTrials.gov. Available online: https:/clinicaltrials.gov/ct2/show/ NCT04185311 (accessed on 28 October 2020).

13. Uusi-Kerttula, H.; Davies, J.A.; Thompson, J.M.; Wongthida, P.; Evgin, L.; Shim, K.G.; Bradshaw, A.; Baker, A.T.; Rizkallah, P.J.; Jones, R.; et al. Ad5NULL-A20: A Tropism-Modified, $\alpha$ v 36 Integrin-Selective Oncolytic Adenovirus for Epithelial Ovarian Cancer Therapies. Clin. Cancer Res. 2018, 24, 4215-4224. [CrossRef]

14. Nguyen, T.V.; Anguiano-Zarate, S.S.; Matchett, W.E.; Barry, M.E.; Barry, M.A. Retargeted and detargeted adenovirus for gene delivery to the muscle. Virology 2018, 514, 118-123. [CrossRef]

15. Belousova, N.; Korokhov, N.; Krendelshchikova, V.; Simonenko, V.; Mikheeva, G.; Triozzi, P.L.; Aldrich, W.A.; Banerjee, P.T.; Gillies, S.D.; Curiel, D.T.; et al. Genetically Targeted Adenovirus Vector Directed to CD40-Expressing Cells. J. Virol. 2003, 77, 11367-11377. [CrossRef]

16. Kaufman, H.L.; Ruby, C.E.; Hughes, T.; Slingluff, C.L. Current status of granulocyte-macrophage colony-stimulating factor in the immunotherapy of melanoma. J. Immunother. Cancer 2014, 2, 11. [CrossRef]

17. Kohlhapp, F.J.; Kaufman, H.L. Molecular pathways: Mechanism of action for talimogene laherparepvec, a new oncolytic virus immunotherapy. Clin. Cancer Res. 2016, 22, 1048-1054. [CrossRef] 
18. Farassati, F.; Yang, A.D.; Lee, P.W.K. Oncogenes in Ras signalling pathway dictate host-cell permissiveness to herpes simplex virus 1. Nat. Cell Biol. 2001, 3, 745-750. [CrossRef]

19. Conry, R.M.; Westbrook, B.; McKee, S.; Norwood, T.G. Talimogene laherparepvec: First in class oncolytic virotherapy. Hum. Vaccin. Immunother. 2018, 14, 839-846. [CrossRef]

20. Shen, Y.; Nemunaitis, J. Herpes simplex virus 1 (HSV-1) for cancer treatment. Cancer Gene Ther. 2006, 13, 975-992. [CrossRef]

21. Rehman, H.; Silk, A.W.; Kane, M.P.; Kaufman, H.L. Into the clinic: Talimogene laherparepvec (T-VEC), a first-in-class intratumoral oncolytic viral therapy. J. Immunother. Cancer 2016, 4, 53. [CrossRef]

22. Andtbacka, R.H.I.; Kaufman, H.L.; Collichio, F.A.; Amatruda, T.; Menunaitis, J.J.; Chesney, J.; Puzanov, I.; Harrington, K.; Zhang, Y.; Chen, L.; et al. Durable complete responses (CR) in patients (pts) with stage IIIB-IV melanoma treated with talimogene laherparepvec (T-VEC) in OPTiM. In Proceedings of the Society for Melanoma Research 2015 Congress, San Francisco, CA USA, 18-21 November 2015; Volume 28, pp. 753-826. [CrossRef]

23. Greig, S.L. Talimogene Laherparepvec: First Global Approval. Drugs 2016, 76, 147-154. [CrossRef]

24. Sun, L.; Funchain, P.; Song, J.M.; Rayman, P.; Tannenbaum, C.; Ko, J.; Mcnamara, M.; Marcela Diaz-Montero, C.; Gastman, B. Talimogene Laherparepvec combined with anti-PD-1 based immunotherapy for unresectable stage III-IV melanoma: A case series. J. Immunother. Cancer 2018, 6, 36. [CrossRef]

25. Seyfried, T.N.; Huysentruyt, L.C. On the Origin of Cancer Metastasis. Crit. Rev. Oncog. 2013, 18, 43-73. [PubMed]

26. Russell, L.; Peng, K.W. The emerging role of oncolytic virus therapy against cancer. Chin. Clin. Oncol. 2018, 7, 16. [PubMed]

27. Kuryk, L.; Møller, A.S.W.; Jaderberg, M. Abscopal effect when combining oncolytic adenovirus and checkpoint inhibitor in a humanized NOG mouse model of melanoma. J. Med. Virol. 2019, 91, 1702-1706. [CrossRef] [PubMed]

28. Wold, W.; Toth, K. Adenovirus Vectors for Gene Therapy, Vaccination and Cancer Gene Therapy. Curr. Gene Ther. 2014, 13, 421-433.

29. Phillips, M.; Stuart, J.; Rodríguez Stewart, R.; Berry, J.; Mainou, B.; Boehme, K. Current understanding of reovirus oncolysis mechanisms. Oncolytic Virother. 2018, 7, 53-63. [CrossRef] [PubMed]

30. Guse, K.; Cerullo, V.; Hemminki, A. Oncolytic vaccinia virus for the treatment of cancer. Expert Opin. Biol. Ther. 2011, 11, 595-608. [CrossRef]

31. HAdV Working Group. Available online: http://hadvwg.gmu.edu/ (accessed on 30 October 2020).

32. Lynch, J.P.; Kajon, A.E. Adenovirus: Epidemiology, Global Spread of Novel Serotypes, and Advances in Treatment and Prevention. Semin. Respir. Crit. Care Med. 2016, 37, 586-602. [CrossRef]

33. Bergelson, J.M.; Cunningham, J.A.; Droguett, G.; Kurt-Jones, E.A.; Krithivas, A.; Hong, J.S.; Horwitz, M.S.; Crowell, R.L.; Finberg, R.W. Isolation of a common receptor for coxsackie B viruses and adenoviruses 2 and 5. Science (80-) 1997, 275, 1320-1323.

34. Gaggar, A.; Shayakhmetov, D.M.; Lieber, A. CD46 is a cellular receptor for group B adenoviruses. Nat. Med. 2003, 9, 1408-1412. [CrossRef]

35. Wang, H.; Li, Z.Y.; Liu, Y.; Persson, J.; Beyer, I.; Möller, T.; Koyuncu, D.; Drescher, M.R.; Strauss, R.; Zhang, X.B.; et al. Desmoglein 2 is a receptor for adenovirus serotypes 3, 7, 11 and 14. Nat. Med. 2011, 17, 96-104. [CrossRef]

36. Arnberg, N.; Edlund, K.; Kidd, A.H.; Wadell, G. Adenovirus Type 37 Uses Sialic Acid as a Cellular Receptor. J. Virol. 2000, 74, 42-48. [CrossRef]

37. Cupelli, K.; Stehle, T. Viral attachment strategies: The many faces of adenoviruses. Curr. Opin. Virol. 2011, 1, 84-91.

38. Burmeister, W.P.; Guilligay, D.; Cusack, S.; Wadell, G.; Arnberg, N. Crystal Structure of Species D Adenovirus Fiber Knobs and Their Sialic Acid Binding Sites. J. Virol. 2004, 78, 7727-7736. [CrossRef]

39. Marttila, M.; Persson, D.; Gustafsson, D.; Liszewski, M.K.; Atkinson, J.P.; Wadell, G.; Arnberg, N. CD46 Is a Cellular Receptor for All Species B Adenoviruses except Types 3 and 7. J. Virol. 2005, 79, 14429-14436.

40. Stewart, P.; Chiu, C.; Huang, S.; Muir, T.; Zhao, Y.; Chait, B.; Mathias, P.; Nemerow, G. Cryo-EM visualization of an exposed RGD epitope on adenovirus that escapes antibody neutralization cell membrane permeabilization. EMBO J. 1997, 16, 1189-1198.

41. Meier, O.; Greber, U.F. Adenovirus endocytosis. J. Gene Med. 2003, 5, 451-462. [CrossRef] 
42. Russell, W.C. Update on adenovirus and its vectors. J. Gen. Virol. 2000, 81, 2573-2604.

43. Russell, W.C. Adenoviruses: Update on structure and function. J. Gen. Virol. 2009, 90, 1-20.

44. Hoeben, R.C.; Uil, T.G. Adenovirus DNA replication. Cold Spring Harb. Perspect. Biol. 2013, 5, a013003. [CrossRef]

45. Hanahan, D.; Weinberg, R.A. Hallmarks of cancer: The next generation. Cell 2011, 144, 646-674.

46. Seymour, L.W.; Fisher, K.D. Oncolytic viruses: Finally delivering. Br. J. Cancer 2016, 114, 357-361. [CrossRef]

47. Cheng, P.H.; Wechman, S.L.; McMasters, K.M.; Zhou, H.S. Oncolytic replication of E1b-deleted adenoviruses. Viruses 2015, 7, 5767-5779. [CrossRef]

48. Everts, B.; Van Der Poel, H.G. Replication-selective oncolytic viruses in the treatment of cancer. Cancer Gene Ther. 2005, 12, 141-161. [CrossRef]

49. Larson, C.; Oronsky, B.; Scicinski, J.; Fanger, G.R.; Stirn, M.; Oronsky, A.; Reid, T.R. Going viral: A review of replication-selective oncolytic adenoviruses. Oncotarget 2015, 6, 19976-19989. [CrossRef]

50. Rodriguez, R.; Schuur, E.R.; Lim, H.Y.; Henderson, G.A.; Simons, J.W.; Henderson, D.R. Prostate Attenuated Replication Competent Adenovirus (ARCA) CN706: A Selective Cytotoxic for Prostate-specific Antigen-positive Prostate Cancer Cells. Cancer Res. 1997, 57, 2559-2563.

51. Tanoue, K.; Shaw, A.R.; Watanabe, N.; Porter, C.; Rana, B.; Gottschalk, S.; Brenner, M.; Suzuki, M. Armed oncolytic adenovirus-expressing PD-L1 mini-body enhances antitumor effects of Chimeric antigen receptor t cells in solid tumors. Cancer Res. 2017, 77, 2040-2051. [CrossRef]

52. Dias, J.D.; Hemminki, O.; Diaconu, I.; Hirvinen, M.; Bonetti, A.; Guse, K.; Escutenaire, S.; Kanerva, A.; Pesonen, S.; Löskog, A.; et al. Targeted cancer immunotherapy with oncolytic adenovirus coding for a fully human monoclonal antibody specific for CTLA-4. Gene Ther. 2012, 19, 988-998. [CrossRef]

53. Cervera-Carrascon, V.; Siurala, M.; Santos, J.M.; Havunen, R.; Tähtinen, S.; Karell, P.; Sorsa, S.; Kanerva, A.; Hemminki, A. TNFa and IL-2 armed adenoviruses enable complete responses by anti-PD-1 checkpoint blockade. Oncoimmunology 2018, 7, e1412902. [CrossRef]

54. Lapteva, N.; Aldrich, M.; Weksberg, D.; Rollins, L.; Goltsova, T.; Chen, S.Y.; Huang, X.F. Targeting the intratumoral dendritic cells by the oncolytic adenoviral vaccine expressing RANTES elicits potent antitumor immunity. J. Immunother. 2009, 32, 145-156. [CrossRef]

55. Kumon, H.; Ariyoshi, Y.; Sasaki, K.; Sadahira, T.; Araki, M.; Ebara, S.; Yanai, H.; Watanabe, M.; Nasu, Y. Adenovirus vector carrying REIC/DKK-3 gene: Neoadjuvant intraprostatic injection for high-risk localized prostate cancer undergoing radical prostatectomy. Cancer Gene Ther. 2016, 23, 400. [CrossRef]

56. Singh, G.; Robinson, C.M.; Dehghan, S.; Schmidt, T.; Seto, D.; Jones, M.S.; Dyer, D.W.; Chodosh, J. Overreliance on the Hexon Gene, Leading to Misclassification of Human Adenoviruses. J. Virol. 2012, 86, 4693-4695. [CrossRef]

57. Pearl, T.M.; Markert, J.M.; Cassady, K.A.; Ghonime, M.G. Oncolytic Virus-Based Cytokine Expression to Improve Immune Activity in Brain and Solid Tumors. Mol. Ther. Oncolytics 2019, 13, 14-21. [CrossRef]

58. ClinicalTrials.gov. Search of: Adenovirus|Cancer-List Results-ClinicalTrials.gov. Available online: https://clinicaltrials.gov/ct2/results?cond=Cancer\&term =Adenovirus\&cntry=\&state=\&city $=\&$ dist $=$ \&Search=Search (accessed on 30 April 2019).

59. Jiang, H.; Gomez-Manzano, C.; Lang, F.; Alemany, R.; Fueyo, J. Oncolytic Adenovirus: Preclinical and Clinical Studies in Patients with Human Malignant Gliomas. Curr. Gene Ther. 2009, 9, 422-427. [CrossRef]

60. Freytag, S.O.; Movsas, B.; Stricker, H. Clinical Trials of Oncolytic Adenovirus-Mediated Gene Therapy. Mol. Ther. 2016, 24, S205. [CrossRef]

61. Abbink, P.; Lemckert, A.A.C.; Ewald, B.A.; Lynch, D.M.; Denholtz, M.; Smits, S.; Holterman, L.; Damen, I.; Vogels, R.; Thorner, A.R.; et al. Comparative Seroprevalence and Immunogenicity of Six Rare Serotype Recombinant Adenovirus Vaccine Vectors from Subgroups B and D. J. Virol. 2007, 81, 4654-4663. [CrossRef]

62. Dakin, R.S.; Parker, A.L.; Delles, C.; Nicklin, S.A.; Baker, A.H. Efficient Transduction of Primary Vascular Cells by the Rare Adenovirus Serotype 49 Vector. Hum. Gene Ther. 2015, 26, 312-319. [CrossRef]

63. Parker, A.L.; Waddington, S.N.; Buckley, S.M.K.; Custers, J.; Havenga, M.J.E.; van Rooijen, N.; Goudsmit, J.; McVey, J.H.; Nicklin, S.A.; Baker, A.H. Effect of Neutralizing Sera on Factor X-Mediated Adenovirus Serotype 5 Gene Transfer. J. Virol. 2009, 83, 479-483. [CrossRef]

64. Alemany, R. Oncolytic Adenoviruses in Cancer Treatment. Biomedicines 2014, 2, 36-49. [CrossRef] 
65. Carlisle, R.C.; Di, Y.; Cerny, A.M.; Sonnen, A.F.P.; Sim, R.B.; Green, N.K.; Subr, V.; Ulbrich, K.; Gilbert, R.J.C.; Fisher, K.D.; et al. Human erythrocytes bind and inactivate type 5 adenovirus by presenting Coxsackie virus-adenovirus receptor and complement receptor 1. Blood 2009, 113, 1909-1918. [CrossRef]

66. Smith, T.; Idamakanti, N.; Kylefjord, H.; Rollence, M.; King, L.; Kaloss, M.; Kaleko, M.; Stevenson, S.C. In Vivo Hepatic Adenoviral Gene Delivery Occurs Independently of the Coxsackievirus-Adenovirus Receptor. Mol. Ther. 2002, 5, 770-779. [CrossRef]

67. Schlipp, A.; Schinner, C.; Spindler, V.; Vielmuth, F.; Gehmlich, K.; Syrris, P.; McKenna, W.J.; Dendorfer, A.; Hartlieb, E.; Waschke, J. Desmoglein-2 interaction is crucial for cardiomyocyte cohesion and function. Cardiovasc. Res. 2014, 104, 245-257. [CrossRef]

68. Nava, P.; Hopkins, A.N.; Laukoetter, M.G.; Green, K.J.; Parkos, C.A.; Nusrat, A. A role of Desmoglein 2 in intestinal epithelial apoptosis. FASEB J. 2007, 21, A192. [CrossRef]

69. Baker, A.T.; Mundy, R.M.; Davies, J.A.; Rizkallah, P.J.; Parker, A.L. Human adenovirus type 26 uses sialic acid-bearing glycans as a primary cell entry receptor. Sci. Adv. 2019, 5, eaax3567. [CrossRef] [PubMed]

70. Parker, A.L.; Waddington, S.N.; Nicol, C.G.; Shayakhmetov, D.M.; Buckley, S.M.; Denby, L.; Kemball-Cook, G.; Ni, S.; Lieber, A.; McVey, J.H.; et al. Multiple vitamin K-dependent coagulation zymogens promote adenovirus-mediated gene delivery to hepatocytes. Blood 2006, 108, 2554-2561. [CrossRef] [PubMed]

71. Waddington, S.N.; McVey, J.H.; Bhella, D.; Parker, A.L.; Barker, K.; Atoda, H.; Pink, R.; Buckley, S.M.K.; Greig, J.A.; Denby, L.; et al. Adenovirus Serotype 5 Hexon Mediates Liver Gene Transfer. Cell 2008, 132, 397-409. [CrossRef]

72. Stewart, P.L.; Nemerow, G.R. Cell integrins: Commonly used receptors for diverse viral pathogens. Trends Microbiol. 2007, 15, 500-507. [CrossRef]

73. Nemerow, G.R. A new link between virus cell entry and inflammation: Adenovirus interaction with integrins induces specific proinflammatory responses. Mol. Ther. 2009, 17, 1490-1491. [CrossRef]

74. Di Paolo, N.C.; Miao, E.A.; Iwakura, Y.; Murali-Krishna, K.; Aderem, A.; Flavell, R.A.; Papayannopoulou, T.; Shayakhmetov, D.M. Virus Binding to a Plasma Membrane Receptor Triggers Interleukin- $\alpha$-Mediated Proinflammatory Macrophage Response In Vivo. Immunity 2009, 31, 110-121. [CrossRef]

75. Bradshaw, A.C.; Coughlan, L.; Miller, A.M.; Alba, R.; Van Rooijen, N.; Nicklin, S.A.; Baker, A.H. Biodistribution and inflammatory profiles of novel penton and hexon double-mutant serotype 5 adenoviruses. J. Control. Release 2012, 164, 394-402. [CrossRef]

76. Fukuhara, H.; Ino, Y.; Todo, T. Oncolytic virus therapy: A new era of cancer treatment at dawn. Cancer Sci. 2016, 107, 1373-1379. [CrossRef]

77. Armendáriz-Borunda, J.; Bastidas-Ramírez, B.E.; Sandoval-Rodríguez, A.; González-Cuevas, J.; Gómez-Meda, B.; García-Bañuelos, J. Production of first generation adenoviral vectors for preclinical protocols: Amplification, purification and functional titration. JBIOSC 2011, 112, 415-421. [CrossRef]

78. Rowe, D.T.; Branton, P.E.; Graham, F.L. The kinetics of synthesis of early viral proteins in KB cells infected with wild-type and transformation-defective host-range mutants of human adenovirus type 5. J. Gen. Virol. 1984, 65, 585-597. [CrossRef]

79. Saha, B.; Parks, R.J. Human adenovirus type 5 vectors deleted of early region 1 (E1) undergo limited expression of early replicative E2 proteins and DNA replication in non-permissive cells. PLoS ONE 2017, 12, e0181012. [CrossRef]

80. Kovesdi, I.; Hedley, S.J. Adenoviral producer cells. Viruses 2010, 2, 1681. [CrossRef]

81. Graham, F.L.; Smiley, J.; Russell, W.C.; Nairn, R. Characteristics of a human cell line transformed by DNA from human adenovirus type 5. J. Gen. Virol. 1977, 36, 59-72. [CrossRef]

82. Fallaux, F.J.; Bout, A.; Van Der Velde, I.; Van Den Wollenberg, D.J.M.; Hehir, K.M.; Keegan, J.; Auger, C.; Cramer, S.J.; Van Ormondt, H.; Van Der Eb, A.J.; et al. New helper cells and matched early region 1-deleted adenovirus vectors prevent generation of replication-competent adenoviruses. Hum. Gene Ther. 1998, 9, 1909-1917. [CrossRef]

83. Suzuki, K.; Alemany, R.; Yamamoto, M.; Curiel, D.T.; Program, G.T. The Presence of the Adenovirus E3 Region Improves the Oncolytic Potency of Conditionally Replicative Adenoviruses 1. Clin. Cancer Res. 2002, 8, 3348-3359.

84. Gorziglia, M.I.; Lapcevich, C.; Roy, S.; Kang, Q.; Kadan, M.; Wu, V.; Pechan, P.; Kaleko, M. Generation of an Adenovirus Vector Lacking E1, E2a, E3, and All of E4 except Open Reading Frame 3. J. Virol. 1999, 73, 6048-6055. [CrossRef] 
85. Alba, R.; Bosch, A.; Chillon, M. Gutless adenovirus: Last-generation adenovirus for gene therapy. Gene Ther. 2005, 12, S18-S27. [CrossRef]

86. Wang, W.; Ji, W.; Hu, H.; Ma, J.; Li, X.; Mei, W.; Xu, Y.; Hu, H.; Yan, Y.; Song, Q.; et al. Survivin promoter-regulated oncolytic adenovirus with Hsp70 gene exerts effective antitumor efficacy in gastric cancer immunotherapy. Oncotarget 2014, 5, 150-160. [CrossRef]

87. Wirth, T.; Zender, L.; Schulte, B.; Mundt, B.; Plentz, R.; Rudolph, K.L.; Manns, M.; Kubicka, S.; Kuhnel, F. A telomerase-dependent conditionally replicating adenovirus for selective treatment of cancer (Cancer Research (2003) 63 (3181-3188)). Cancer Res. 2018, 78, 6027.

88. Berns, K.I.; Giraud, C. Adenovirus and Adeno-Associated Virus as Vectors for Gene Therapy. Ann. N. Y. Acad. Sci. 1995, 772, 95-104. [PubMed]

89. Suzuki, S.; Kofune, H.; Uozumi, K.; Yoshimitsu, M.; Arima, N.; Ishitsuka, K.; Ueno, S.I.; Kosai, K.I. A survivin-responsive, conditionally replicating adenovirus induces potent cytocidal effects in adult T-cell leukemia/lymphoma. BMC Cancer 2019, 19, 516.

90. Doloff, J.C.; Waxman, D.J.; Jounaidi, Y. Human Telomerase Reverse Transcriptase Promoter-Driven Oncolytic Adenovirus with E1B-19 kDa and E1B-55 kDa Gene Deletions. Hum. Gene Ther. 2008, 19, 1383-1399. [CrossRef] [PubMed]

91. Fueyo, J.; Gomez-Manzano, C.; Alemany, R.; Lee, P.S.Y.; McDonnell, T.J.; Mitlianga, P.; Shi, Y.X.; Levin, V.A.; Yung, W.K.A.; Kyritsis, A.P. A mutant oncolytic adenovirus targeting the Rb pathway produces anti-glioma effect in vivo. Oncogene 2000, 19, 2-12. [CrossRef] [PubMed]

92. Hulin-Curtis, S.L.; Davies, J.A.; Jones, R.; Hudson, E.; Hanna, L.; Chester, J.D.; Parker, A.L. Histone deacetylase inhibitor trichostatin A sensitises cisplatinresistant ovarian cancer cells to oncolytic adenovirus. Oncotarget 2018, 9, 26328-26341. [CrossRef] [PubMed]

93. Konecny, G.E.; Winterhoff, B.; Kolarova, T.; Qi, J.; Manivong, K.; Dering, J.; Yang, G.; Chalukya, M.; Wang, H.J.; Anderson, L.; et al. Expression of p16 and retinoblastoma determines response to CDK4/6 inhibition in ovarian cancer. Clin. Cancer Res. 2011, 17, 1591-1602.

94. Sellers, W.R.; Kaelin, W.G. Role of the retinoblastoma protein in the pathogenesis of human cancer. J. Clin. Oncol. 1997, 15, 3301-3312. [CrossRef]

95. Gros, A.; Martínez-Quintanilla, J.; Puig, C.; Guedan, S.; Molleví, D.G.; Alemany, R.; Cascallo, M. Bioselection of a gain of function mutation that enhances adenovirus 5 release and improves its antitumoral potency. Cancer Res. 2008, 68, 8928-8937.

96. Dong, W.; Van Ginkel, J.W.H.; Au, K.Y.; Alemany, R.; Meulenberg, J.J.M.; Van Beusechem, V.W. ORCA-010, a novel potency-enhanced oncolytic adenovirus, exerts strong antitumor activity in preclinical models. Hum. Gene Ther. 2014, 25, 897-904.

97. Ganly, I.; Kirn, D.; Eckhardt, S.G.; Rodriguez, G.I.; Soutar, D.S.; Otto, R.; Robertson, A.G.; Park, O.; Gulley, M.L.; Heise, C.; et al. A Phase I Study of Onyx-015, an E1B Attenuated Adenovirus, Administered Intratumorally to Patients with Recurrent Head and Neck Cancer. Clin. Cancer Res. 2000, 6, 798. [PubMed]

98. Garber, K. China approves world's first oncolytic virus therapy for cancer treatment. J. Natl. Cancer Inst. 2006, 98, 298-300. [CrossRef] [PubMed]

99. Ries, S.; Korn, W.M. ONYX-015: Mechanisms of action and clinical potential of a replication-selective adenovirus. Br. J. Cancer 2002, 86, 5-11. [CrossRef] [PubMed]

100. Muller, P.A.J.; Vousden, K.H. P53 mutations in cancer. Nat. Cell Biol. 2013, 15, 2-8. [CrossRef] [PubMed]

101. O'Shea, C.C.; Johnson, L.; Bagus, B.; Choi, S.; Nicholas, C.; Shen, A.; Boyle, L.; Pandey, K.; Soria, C.; Kunich, J.; et al. Late viral RNA export, rather than p53 inactivation, determines ONYX-015 tumor selectivity. Cancer Cell 2004, 6, 611-623. [CrossRef] [PubMed]

102. Raman, S.S.; Hecht, J.R.; Chan, E. Talimogene laherparepvec: Review of its mechanism of action and clinical efficacy and safety. Immunotherapy 2019, 11, 705-723. [CrossRef] [PubMed]

103. Kirn, D. Oncolytic virotherapy for cancer with the adenovirus dl1520 (Onyx-015): Results of Phase I and II trials. Expert Opin. Biol. Ther. 2001, 1, 525-538. [CrossRef]

104. Ram, Z.; Culver, K.W.; Oshiro, E.M.; Viola, J.J.; Devroom, H.L.; Otto, E.; Long, Z.; Chiang, Y.; Mcgarrity, G.J.; Muul, L.M.; et al. Therapy of malignant brain tumors by intratumoral implantation of retroviral vector-producing cells. Nat. Med. 1997, 3, 1354-1361. [CrossRef] 
105. Sterman, D.H.; Treat, J.; Litzky, L.A.; Amin, K.M.; Coonrod, L.; Molnar-Kimber, K.; Recio, A.; Knox, L.; Wilson, J.M.; Albelda, S.M.; et al. Adenovirus-mediated herpes simplex virus thymidine kinase/ganciclovir gene therapy in patients with localized malignancy: Results of a phase I clinical trial in malignant mesothelioma. Hum. Gene Ther. 1998, 9, 1083-1092. [CrossRef]

106. Dhar, D.; Spencer, J.F.; Toth, K.; Wold, W.S.M. Pre-existing immunity and passive immunity to adenovirus 5 prevents toxicity caused by an oncolytic adenovirus vector in the syrian hamster model. Mol. Ther. 2009, 17, 1724-1732. [CrossRef]

107. Belousova, N.; Mikheeva, G.; Xiong, C.; Stagg, L.J.; Gagea, M.; Fox, P.S.; Bassett, R.L.; Ladbury, J.E.; Braun, M.B.; Stehle, T.; et al. Native and engineered tropism of vectors derived from a rare species D adenovirus serotype 43. Oncotarget 2016, 7, 53414-53429. [CrossRef] [PubMed]

108. Greig, J.A.; Buckley, S.M.K.; Waddington, S.N.; Parker, A.L.; Bhella, D.; Pink, R.; Rahim, A.A.; Morita, T.; Nicklin, S.A.; McVey, J.H.; et al. Influence of coagulation factor $X$ on in vitro and in vivo gene delivery by adenovirus (Ad) 5, Ad35, and chimeric Ad5/Ad35 vectors. Mol. Ther. 2009, 17, 1683-1691. [CrossRef] [PubMed]

109. Alba, R.; Bradshaw, A.C.; Parker, A.L.; Bhella, D.; Waddington, S.N.; Nicklin, S.A.; Van Rooijen, N.; Custers, J.; Goudsmit, J.; Barouch, D.H.; et al. Identification of coagulation factor (F)X binding sites on the adenovirus serotype 5 hexon: Effect of mutagenesis on FX interactions and gene transfer. Blood 2009, 114, 965-971. [CrossRef]

110. Gao, J.; Zhang, W.; Ehrhardt, A. Expanding the spectrum of adenoviral vectors for cancer therapy. Cancers (Basel) 2020, 12, 1139. [CrossRef] [PubMed]

111. Mach, N.; Gao, J.; Schaffarczyk, L.; Janz, S.; Ehrke-Schulz, E.; Dittmar, T.; Ehrhardt, A.; Zhang, W. Spectrum-wide exploration of human adenoviruses for breast cancer therapy. Cancers (Basel) 2020, 12, 1403. [CrossRef]

112. Kanerva, A.; Wang, M.; Bauerschmitz, G.J.; Lam, J.T.; Desmond, R.A.; Bhoola, S.M.; Barnes, M.N.; Alvarez, R.D.; Siegal, G.P.; Curiel, D.T.; et al. Gene transfer to ovarian cancer versus normal tissues with fiber-modified adenoviruses. Mol. Ther. 2002, 5, 695-704. [CrossRef]

113. Krasnykh, V.N.; Mikheeva, G.V.; Douglas, J.T.; Curiel, D.T. Generation of recombinant adenovirus vectors with modified fibers for altering viral tropism. J. Virol. 1996, 70, 6839-6846. [CrossRef]

114. Kuhn, I.; Harden, P.; Bauzon, M.; Chartier, C.; Nye, J.; Thorne, S.; Reid, T.; Ni, S.; Lieber, A.; Fisher, K.; et al. Directed evolution generates a novel oncolytic virus for the treatment of colon cancer. PLOS ONE 2008, 3, e2409. [CrossRef]

115. Garcia-Carbonero, R.; Salazar, R.; Duran, I.; Osman-Garcia, I.; Paz-Ares, L.; Bozada, J.M.; Boni, V.; Blanc, C.; Seymour, L.; Beadle, J.; et al. Phase 1 study of intravenous administration of the chimeric adenovirus enadenotucirev in patients undergoing primary tumor resection. J. Immunother. Cancer 2017, 5, 71. [CrossRef]

116. McNeish, I.A.; Oza, A.M.; Coleman, R.L.; Scott, C.L.; Konecny, G.E.; Tinker, A.; O'Malley, D.M.; Brenton, J.; Kristeleit, R.S.; Bell-McGuinn, K.; et al. Results of ARIEL2: A Phase 2 trial to prospectively identify ovarian cancer patients likely to respond to rucaparib using tumor genetic analysis. J. Clin. Oncol. 2015, 33, 5508. [CrossRef]

117. Dyer, A.; Di, Y.; Calderon, H.; Illingworth, S.; Kueberuwa, G.; Tedcastle, A.; Jakeman, P.; Chia, S.L.; Brown, A.; Silva, M.A.; et al. Oncolytic Group B Adenovirus Enadenotucirev Mediates Non-apoptotic Cell Death with Membrane Disruption and Release of Inflammatory Mediators. Mol. Ther. Oncolytics 2017, 4, 18-30. [CrossRef] [PubMed]

118. Cohen, C.J.; Shieh, J.T.C.; Pickles, R.J.; Okegawa, T.; Hsieh, J.T.; Bergelson, J.M. The coxsackievirus and adenovirus receptor is a transmembrane component of the tight junction. Proc. Natl. Acad. Sci. USA 2001, 98, 15191-15196. [CrossRef] [PubMed]

119. Korn, W.M.; Macal, M.; Christian, C.; Lacher, M.D.; McMillan, A.; Rauen, K.A.; Warren, R.S.; Ferrell, L. Expression of the coxsackievirus- and adenovirus receptor in gastrointestinal cancer correlates with tumor differentiation. Cancer Gene Ther. 2006, 13, 792-797. [CrossRef] [PubMed]

120. Sachs, M.D.; Rauen, K.A.; Ramamurthy, M.; Dodson, J.L.; De Marzo, A.M.; Putzi, M.J.; Schoenberg, M.P.; Rodriguez, R. Integrin $\alpha \mathrm{v}$ and coxsackie adenovirus receptor expression in clinical bladder cancer. Urology 2002, 60, 531-536. [CrossRef] 
121. Rauen, K.A.; Sudilovsky, D.; Le, J.L.; Chew, K.L.; Hann, B.; Weinberg, V.; Schmitt, L.D.; Mccormick, F. Expression of the Coxsackie Adenovirus Receptor in Normal Prostate and in Primary and Metastatic Prostate Carcinoma: Potential Relevance to Gene Therapy 1. Cancer Res. 2002, 62, 3812-3818. [PubMed]

122. Nicklin, S.A.; Von Seggern, D.J.; Work, L.M.; Pek, D.C.K.; Dominiczak, A.F.; Nemerow, G.R.; Baker, A.H. Ablating adenovirus type 5 fiber-CAR binding and HI loop insertion of the SIGYPLP peptide generate an endothelial cell-selective adenovirus. Mol. Ther. 2001, 4, 534-542. [CrossRef] [PubMed]

123. Wickham, T.J.; Tzeng, E.; Shears Ii, L.L.; Roelvink, P.W.; Li, Y.; Lee, G.M.; Brough, D.E.; Lizonova, A.; Kovesdi, I. Increased In Vitro and In Vivo Gene Transfer by Adenovirus Vectors Containing Chimeric Fiber Proteins. J. Virol. 1997, 71, 8221-8229. [CrossRef] [PubMed]

124. Parker, A.; Davies, J.; Marlow, G.; Uusi-Kerttula, H.; Seaton, G.; Piggott, L.; Clarkson, R.; Chester, J. Ad5 (NULL)-A20-a precision virotherapy that efficiently and selectively targets $\alpha \mathrm{v} \beta 6$ positive cancers following intravenous administration. Br. J. Cancer 2019, 121, 16.

125. Nakamura, T.; Sato, K.; Hamada, H. Reduction of Natural Adenovirus Tropism to the Liver by both Ablation of Fiber-Coxsackievirus and Adenovirus Receptor Interaction and Use of Replaceable Short Fiber. J. Virol. 2003, 77, 2512-2521. [CrossRef] [PubMed]

126. Schoggins, J.W.; Gall, J.G.D.; Falck-Pedersen, E. Subgroup B and F Fiber Chimeras Eliminate Normal Adenovirus Type 5 Vector Transduction In Vitro and In Vivo. J. Virol. 2003, 77, 1039-1048. [CrossRef]

127. Kashentseva, E.A.; Douglas, J.T.; Zinn, K.R.; Curiel, D.T.; Dmitriev, I.P. Targeting of Adenovirus Serotype 5 Pseudotyped with Short Fiber from Serotype 41 to c-erbB2-Positive Cells using Bispecific Single-Chain Diabody. J. Mol. Biol. 2009, 388, 443-461. [CrossRef] [PubMed]

128. Hofherr, S.E.; Shashkova, E.V.; Weaver, E.A.; Khare, R.; Barry, M.A. Modification of adenoviral vectors with polyethylene glycol modulates in vivo tissue tropism and gene expression. Mol. Ther. 2008, 16, 1276-1282. [CrossRef] [PubMed]

129. Kreppel, F.; Kochanek, S. Modification of adenovirus gene transfer vectors with synthetic polymers: A scientific review and technical guide. Mol. Ther. 2008, 16, 16-29. [CrossRef] [PubMed]

130. Kim, J.; Kim, P.H.; Kim, S.W.; Yun, C.O. Enhancing the therapeutic efficacy of adenovirus in combination with biomaterials. Biomaterials 2012, 33, 1838-1850. [CrossRef] [PubMed]

131. Kaufmann, J.K.; Nettelbeck, D.M. Virus chimeras for gene therapy, vaccination, and oncolysis: Adenoviruses and beyond. Trends Mol. Med. 2012, 18, 365-376. [CrossRef] [PubMed]

132. Silver, J.; Mei, Y.-F. Transduction and Oncolytic Profile of a Potent Replication-Competent Adenovirus 11p Vector (RCAd11pGFP) in Colon Carcinoma Cells. PLoS ONE 2011, 6, e17532. [CrossRef]

133. Rein, D.T.; Volkmer, A.; Beyer, I.M.; Curiel, D.T.; Janni, W.; Dragoi, A.; Hess, A.P.; Maass, N.; Baldus, S.E.; Bauerschmitz, G.; et al. Treatment of chemotherapy resistant ovarian cancer with a MDR1 targeted oncolytic adenovirus. Gynecol. Oncol. 2011, 123, 138-146. [CrossRef]

134. Nakayama, M.; Both, G.W.; Banizs, B.; Tsuruta, Y.; Yamamoto, S.; Kawakami, Y.; Douglas, J.T.; Tani, K.; Curiel, D.T.; Glasgow, J.N. An adenovirus serotype 5 vector with fibers derived from ovine atadenovirus demonstrates CAR-independent tropism and unique biodistribution in mice. Virology 2006, 350, 103-115. [CrossRef]

135. Nicklin, S.A.; Wu, E.; Nemerow, G.R.; Baker, A.H. The influence of adenovirus fiber structure and function on vector development for gene therapy. Mol. Ther. 2005, 12, 384-393. [CrossRef]

136. Shayakhmetov, D.M.; Lieber, A. Dependence of Adenovirus Infectivity on Length of the Fiber Shaft Domain. J. Virol. 2000, 74, 10274-10286. [CrossRef]

137. Xial, D.; Henry2, L.J.; Gerard2, R.D.; Eisenhoferl, J. Crystal structure of the receptor-binding domain of adenovirus type 5 fiber protein at 1.7 A resolution. Structure 1994, 2, 1259-1270.

138. Hemminki, A.; Wang, M.; Desmond, R.A.; Strong, T.V.; Alvarez, R.D.; Curiel, D.T. Serum and ascites neutralizing antibodies in ovarian cancer patients treated with intraperitoneal adenoviral gene therapy. Hum. Gene Ther. 2002, 13, 1505-1514. [CrossRef] [PubMed]

139. Kiyokawa, J.; Wakimoto, H. Preclinical And Clinical Development Of Oncolytic Adenovirus For The Treatment Of Malignant Glioma. Oncolytic Virotherapy 2019, 8, 27-37. [CrossRef] [PubMed]

140. Krasnykh, V.; Dmitriev, I.; Mikheeva, G.; Miller, C.R.; Belousova, N.; Curiel, D.T. Characterization of an Adenovirus Vector Containing a Heterologous Peptide Epitope in the HI Loop of the Fiber Knob. J. Virol. 1998, 72, 1844-1852. [CrossRef] [PubMed] 
141. Coughlan, L.; Uusi-Kerttula, H.; Ma, J.; Degg, B.P.; Parker, A.L.; Baker, A.H. Retargeting adenovirus serotype 48 fiber knob domain by peptide incorporation. Hum. Gene Ther. 2014, 25, 385-394. [CrossRef]

142. Uusi-Kerttula, H.; Davies, J.; Coughlan, L.; Hulin-Curtis, S.; Jones, R.; Hanna, L.; Chester, J.D.; Parker, A.L. Pseudotyped $\alpha \mathrm{v} \beta 6$ integrin-targeted adenovirus vectors for ovarian cancer therapies. Oncotarget 2016, 7, 27926-27937. [CrossRef]

143. Magnusson, M.K.; Henning, P.; Myhre, S.; Wikman, M.; Uil, T.G.; Friedman, M.; Andersson, K.M.E.; Hong, S.S.; Hoeben, R.C.; Habib, N.A.; et al. Adenovirus 5 vector genetically re-targeted by an Affibody molecule with specificity for tumor antigen HER2/neu. Cancer Gene Ther. 2007, 14, 468-479. [CrossRef]

144. Magnusson, M.K.; Kraaij, R.; Leadley, R.M.; De Ridder, C.M.A.; Van Weerden, W.M.; Van Schie, K.A.J.; Van Der Kroeg, M.; Hoeben, R.C.; Maitland, N.J.; Lindholm, L. A transductionally retargeted adenoviral vector for virotherapy of her2/neu-expressing prostate cancer. Hum. Gene Ther. 2012, 23, 70-82. [CrossRef]

145. Whilding, L.M.; Parente-Pereira, A.C.; Zabinski, T.; Davies, D.M.; Petrovic, R.M.G.; Kao, Y.V.; Saxena, S.A.; Romain, A.; Costa-Guerra, J.A.; Violette, S.; et al. Targeting of Aberrant $\alpha v \beta 6$ Integrin Expression in Solid Tumors Using Chimeric Antigen Receptor-Engineered T Cells. Mol. Ther. 2017, 25, 2427. [CrossRef]

146. Ahmed, N.; Riley, C.; Rice, G.E.; Quinn, M.A.; Baker, M.S. $\alpha \mathrm{v} \beta 6$ integrin-A marker for the malignant potential of epithelial ovarian cancer. J. Histochem. Cytochem. 2002, 50, 1371-1379. [CrossRef]

147. Reader, C.S.; Vallath, S.; Steele, C.W.; Haider, S.; Brentnall, A.; Desai, A.; Moore, K.M.; Jamieson, N.B.; Chang, D.; Bailey, P.; et al. The integrin $\alpha \mathrm{v} \beta 6$ drives pancreatic cancer through diverse mechanisms and represents an effective target for therapy. J. Pathol. 2019, 249, 332-342. [CrossRef]

148. Sun, Q.; Sun, F.; Wang, B.; Liu, S.; Niu, W.; Liu, E.; Peng, C.; Wang, J.; Gao, H.; Liang, B.; et al. Interleukin-8 promotes cell migration through integrin $\alpha \mathrm{v} \beta 6$ upregulation in colorectal cancer. Cancer Lett. 2014, 354, 245-253. [CrossRef]

149. Hausner, S.H.; DiCara, D.; Marik, J.; Marshall, J.F.; Sutcliffe, J.L. Use of a peptide derived from foot-and-mouth disease virus for the noninvasive imaging of human cancer: Generation and evaluation of $4-\left[{ }^{18} \mathrm{~F}\right]$ fluorobenzoyl A20FMDV2 for in vivo imaging of integrin $\alpha v \beta 6$ expression with positron emission tomography. Cancer Res. 2007, 67, 7833-7840. [CrossRef] [PubMed]

150. Moore, K.M.; Desai, A.; de Luxán Delgado, B.; Trabulo, S.M.D.; Reader, C.; Brown, N.F.; Murray, E.R.; Brentnall, A.; Howard, P.; Masterson, L.; et al. Integrin $\alpha \mathrm{v} \beta 6$-specific therapy for pancreatic cancer developed from foot-and-mouth-disease virus. Theranostics 2020, 10, 2930-2942. [CrossRef] [PubMed]

151. Robertson, S.; Parker, A.L.; Clarke, C.; Duffy, M.R.; Alba, R.; Nicklin, S.A.; Bakerk, A.H. Retargeting FX-binding-ablated HAdV-5 to vascular cells by inclusion of the RGD-4C peptide in hexon hypervariable region 7 and the HI loop. J. Gen. Virol. 2016, 97, 1911-1916. [CrossRef] [PubMed]

152. Vigne, E.; Mahfouz, I.; Dedieu, J.-F.; Brie, A.; Perricaudet, M.; Yeh, P. RGD Inclusion in the Hexon Monomer Provides Adenovirus Type 5-Based Vectors with a Fiber Knob-Independent Pathway for Infection. J. Virol. 1999, 73, 5156-5161. [CrossRef]

153. Hulin-Curtis, S.L.; Davies, J.A.; Nestić, D.; Bates, E.A.; Baker, A.T.; Cunliffe, T.G.; Majhen, D.; Chester, J.D.; Parker, A.L. Identification of folate receptor $\alpha(\mathrm{FR} \alpha)$ binding oligopeptides and their evaluation for targeted virotherapy applications. Cancer Gene Ther. 2020, 1-14. [CrossRef] [PubMed]

154. Maruta, F.; Parker, A.L.; Fisher, K.D.; Hallissey, M.T.; Ismail, T.; Rowlands, D.C.; Chandler, L.A.; Kerr, D.J.; Seymour, L.W. Identification of FGF receptor-binding peptides for cancer gene therapy. Cancer Gene Ther. 2002, 9, 543-552. [CrossRef]

155. Uusi-Kerttula, H.; Legut, M.; Davies, J.; Jones, R.; Hudson, E.; Hanna, L.; Stanton, R.J.; Chester, J.D.; Parker, A.L. Incorporation of Peptides Targeting EGFR and FGFR1 into the Adenoviral Fiber Knob Domain and Their Evaluation as Targeted Cancer Therapies. Hum. Gene Ther. 2015, 26, 320-329. [CrossRef]

156. Ehrlich, G.K.; Berthold, W.; Bailon, P. Phage Display Technology: Affinity Selection by Biopanning. In Affinity Chromatography; Humana Press: Totowa, NJ, USA, 2000; Volume 147, pp. 195-208.

157. Li, Z.; Zhao, R.; Wu, X.; Sun, Y.; Yao, M.; Li, J.; Xu, Y.; Gu, J. Identification and characterization of a novel peptide ligand of epidermal growth factor receptor for targeted delivery of therapeutics. FASEB J. 2005, 19, 1978-1985. [CrossRef]

158. Urbanelli, L.; Ronchini, C.; Fontana, L.; Menard, S.; Orlandi, R.; Monaci, P. Targeted gene transduction of mammalian cells expressing the HER2/neu receptor by filamentous phage 1 1Edited by J. Karn. J. Mol. Biol. 2001, 313, 965-976. [CrossRef] 
159. Senol, S.; Ceyran, A.B.; Aydin, A.; Zemheri, E.; Ozkanli, S.; Kösemetin, D.; Sehitoglu, I.; Akalin, I. Folate receptor $\alpha$ expression and significance in endometrioid endometrium carcinoma and endometrial hyperplasia. Int. J. Clin. Exp. Pathol. 2015, 8, 5633-5641.

160. Lupold, S.E.; Kudrolli, T.A.; Chowdhury, W.H.; Wu, P.; Rodriguez, R. A novel method for generating and screening peptides and libraries displayed on adenovirus fiber. Nucleic Acids Res. 2007, 35, 138. [CrossRef]

161. Brown, K.C. Peptidic tumor targeting agents: The road from phage display peptide selections to clinical applications. Curr. Pharm. Des. 2010, 16, 1040-1054. [CrossRef]

Publisher's Note: MDPI stays neutral with regard to jurisdictional claims in published maps and institutional affiliations.

(C) 2020 by the authors. Licensee MDPI, Basel, Switzerland. This article is an open access article distributed under the terms and conditions of the Creative Commons Attribution (CC BY) license (http://creativecommons.org/licenses/by/4.0/). 